\title{
Review \\ Cadmium-Induced Kidney Injury: Oxidative Damage as a Unifying Mechanism
}

\author{
Liang-Jun Yan * ${ }^{\mathbb{C}}$ and Daniel C. Allen \\ Department of Pharmaceutical Sciences, College of Pharmacy, University of North Texas Health Science Center, \\ Fort Worth, TX 76107, USA; danielallen@my.unthsc.edu \\ * Correspondence: liang-jun.yan@unthsc.edu; Tel.: +1-817-735-2386; Fax: +1-817-735-2603
}

Citation: Yan, L.-J.; Allen, D.C.

Cadmium-Induced Kidney Injury: Oxidative Damage as a Unifying Mechanism. Biomolecules 2021, 11, 1575. https://doi.org/10.3390/ biom 11111575

Academic Editor:

Theodoros Eleftheriadis

Received: 16 September 2021

Accepted: 20 October 2021

Published: 23 October 2021

Publisher's Note: MDPI stays neutral with regard to jurisdictional claims in published maps and institutional affiliations.

Copyright: (c) 2021 by the authors. Licensee MDPI, Basel, Switzerland. This article is an open access article distributed under the terms and conditions of the Creative Commons Attribution (CC BY) license (https:// creativecommons.org/licenses/by/ $4.0 /)$.

\begin{abstract}
Cadmium is a nonessential metal that has heavily polluted the environment due to human activities. It can be absorbed into the human body via the gastrointestinal tract, respiratory tract, and the skin, and can cause chronic damage to the kidneys. The main site where cadmium accumulates and causes damage within the nephrons is the proximal tubule. This accumulation can induce dysfunction of the mitochondrial electron transport chain, leading to electron leakage and production of reactive oxygen species (ROS). Cadmium may also impair the function of NADPH oxidase, resulting in another source of ROS. These ROS together can cause oxidative damage to DNA, proteins, and lipids, triggering epithelial cell death and a decline in kidney function. In this article, we also reviewed evidence that the antioxidant power of plant extracts, herbal medicines, and pharmacological agents could ameliorate cadmium-induced kidney injury. Finally, a model of cadmium-induced kidney injury, centering on the notion that oxidative damage is a unifying mechanism of cadmium renal toxicity, is also presented. Given that cadmium exposure is inevitable, further studies using animal models are warranted for a detailed understanding of the mechanism underlying cadmium induced ROS production, and for the identification of more therapeutic targets.
\end{abstract}

Keywords: cadmium; kidney injury; renal toxicity; mitochondria; oxidative damage; proximal tubule

\section{Introduction}

The kidney is a vital organ that performs critical physiological functions by actively filtering excess fluid and secreting waste products including urea, uric acid, and creatinine $[1,2]$. It is through the process of filtration and reabsorption that the kidneys maintain homeostasis of water, acid-base and, electrolytes [3]. Moreover, the kidney also secretes hormones that participate in the control and regulation of hemodynamics, red blood cell production, and vitamin D maturation [3]. Under abnormal conditions such as fasting and insulin resistance, the kidney can also make glucose via the gluconeogenic pathway [4-6] using noncarbohydrate precursors such as pyruvate, alanine, lactate, and glycerol [7].

The kidney is also vulnerable to injuries caused by numerous challenges such as ischemia [8-12], drug toxicity [13-19], environmental heavy metal exposure [20-27], hypertension [28-30], immune injury [31,32], and diabetes [33-36]. In terms of environmental risk factors, human kidney disease caused by environmental pollutants and occupational-linked toxins is a major public health issue [37]. Cadmium is a toxic heavy metal mainly derived from chemical stabilizers, pigments, nickel-cadmium batteries, and metal coatings and alloys [38]. It is also a toxic element in cigarettes [38]. Accordingly, contaminated soil, air, drinking water, food chains [39,40], and cigarettes, as well as children's plastic toys [41], are the major sources of human cadmium exposure. Numerous studies focusing on cadmium toxicity have established that the kidney is a primary organ site for cadmium accumulation [42,43]. Indeed, cadmium exposure has been tightly associated with renal dysfunction and kidney damage, causing polyuria and proteinuria $[23,24]$. The proximal tubule is the major site of cadmium deposition, accumulation, and damage because of the development of proximal tubular 
epithelial cell hypertrophy with occurrence of polyuria and proteinuria [44-46]. Therefore, it is important to counteract cadmium-induced kidney injury to safeguard kidney function.

\section{Cadmium Absorption, Transportation, and Accumulation in the Kidney}

Cadmium has a high affinity toward thiol groups and can selectively form complexes with proteins and peptides whose cysteine residues are available for cadmium binding [47,48]. After ingestion of cadmium-contaminated water, food, and/or cigarette smoking, cadmium can be absorbed into circulation via the gastrointestinal tract, respiratory tract, or the skin [49-51]. Once in the blood, cadmium binds to albumin and other cysteine-containing proteins and peptides such as glutathione [37] and gets transported via many avenues to the liver [37] whereby the heavy metal is then released and induces the expression of metallothionein that then binds tightly to cadmium $[52,53]$. This binding serves the purpose of detoxification as the cadmium-metallothionein complex is usually considered nontoxic [54]. The cadmiummetallothionein complex can be released into the bloodstream and is then filtered at the glomerulus and reabsorbed by the proximal tubular epithelial cells [55]. This is followed by release of cadmium from the degradation of the cadmium-metallothionein complex [55]. The free form of cadmium in the proximal tubular region of the nephron can then bind to preexisting renal metallothionein and induce further renal expression of metallothionein [50]. When renal metallothionein is exhausted [56,57], the nonmetallothionein bound cadmium accumulates and induces nephrotoxicity $[49-51,58,59]$, primarily in the proximal tubular region (Figure 1) via generation of oxygen free radicals [60-62]. As up to $50 \%$ of the body's cadmium pool can deposit in the kidney [37] and the half-life of cadmium in the kidney is approximately 45 years [63-67], cadmium-caused renal toxicity can pose a major threat to human health, particularly in countries where environmental control and regulation are lacking. It should be noted that while the binding of cadmium to metallothionein is a well-established mechanism, other thiol-containing proteins and peptides such as albumin and glutathione can also bind cadmium, leading to functional impairment of these cadmium bound target proteins and peptides [50].

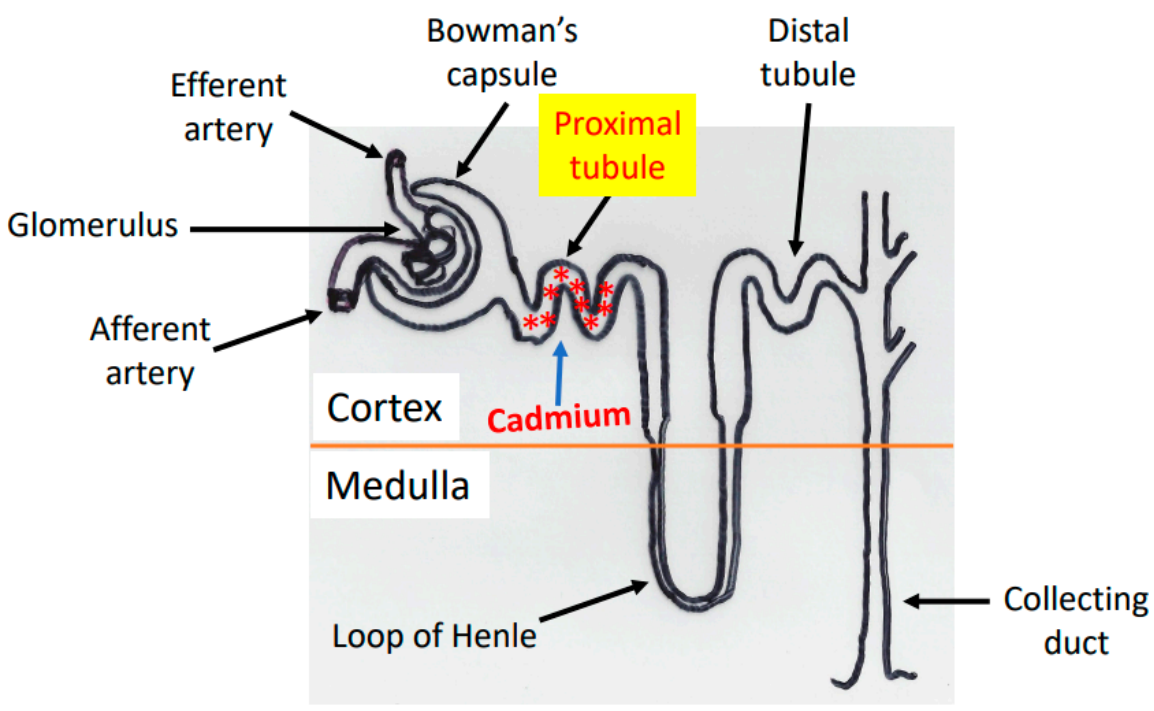

Figure 1. Diagram showing the proximal convoluted tubule as the major site of cadmium accumulation and toxicity in the nephrons "**".

\section{Cadmium-Induced Animal Models of Kidney Injury}

Given the fact that human cadmium exposure is a chronic process at a very low level, any investigation of cadmium renal toxicity would require many years of monitoring and follow-up studies. Therefore, animal models using mice or rats have been widely used to replicate the pathophysiological mechanisms of cadmium renal toxicity $[39,40,42,68]$. In numerous cases, high doses of cadmium were applied in these animal models to shorten the 
duration of the studies and facilitate the process of obtaining insights into the mechanisms of cadmium renal toxicity. As mentioned above, studies using rodent models as well as results from human subjects have established that the primary target of cadmium in the nephron is the proximal tubule, whereby cadmium causes overall dysfunction of the epithelial cells $[51,69,70]$, resulting in polyuria and proteinuria [50,51]. There is also an increase in urinary excretion of amino acids, glucose, and electrolytes such as $\mathrm{Na}^{+} . \mathrm{K}^{+}$, and $\mathrm{Ca}^{2+}[50,51]$. Increasing evidence also indicates that a variety of risk factors such as aging [71], malnutrition [72], obesity [73-75], and diabetes [27,76] can further superimpose on cadmium renal toxicity and aggravate cadmium-induced renal dysfunction.

It should be stressed that in animal model studies of cadmium renal injury, a variety of doses, routes, and duration of exposures have been performed. The purpose of all these approaches is to try to replicate or recapitulate the toxico-kinetics and underlying mechanisms of long-term, low-level exposure that commonly occur in humans [50].

\section{Mechanisms of Cadmium-Induced Renal Toxicity}

What is the proposed mechanism of cadmium-induced kidney injury? Based on numerous studies, all injurious pathways converge on ROS production and culminate in oxidative stress [77-81], which suggests that oxidative damage is a unifying mechanism of cadmiuminduced renal toxicity and injury. We also think that the major sources of ROS causing oxidative damage in this context are mitochondria and NADPH oxidase, described as follows.

\section{Sources of Reactive Oxygen Species}

\subsection{Mitochondria}

Mitochondria are well known as the intracellular site of ROS production [82-85]. Among the electron transport chain components complexes I, II and III have all been established as major sites of ROS production [86-89]. These sites are not perfect even under normal conditions and can leak electrons out of the transport chain [90,91] (Figure 2). The leaked electrons can then partially reduce oxygen to form superoxide anion, which is the precursor of all other reactive oxygen species including $\mathrm{H}_{2} \mathrm{O}_{2}$, hydroxyl radical, and peroxynitrite [92,93] (Figure 3). Additionally, dihydrolipoamide dehydrogenase involved enzyme complexes such as pyruvate dehydrogenase, $\alpha$-ketoglutarate dehydrogenase, and branched chain amino acid dehydrogenase can also produce superoxide anion in a variety of experimental and pathological conditions [94-97].

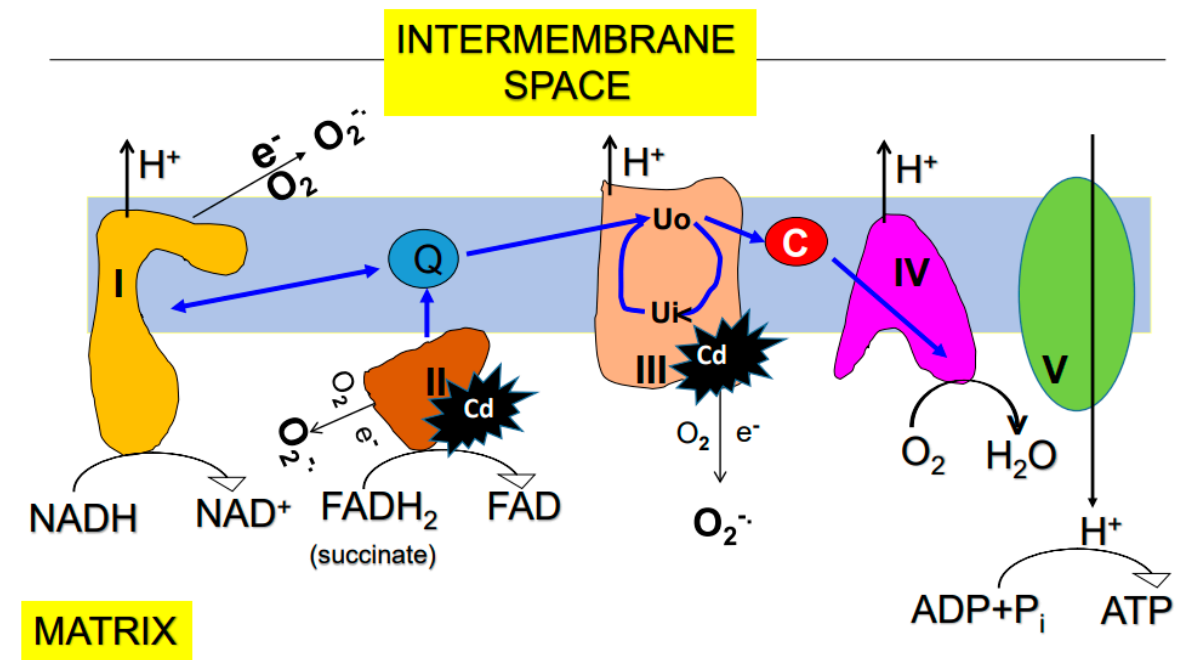

Figure 2. Diagram showing mitochondrial electron transport chain and oxidative phosphorylation. Complexes I, II, and III all can generate superoxide anion. This process can be enhanced by pathophysiological conditions such as cadmium exposure and accumulation. Note that it has been suggested that complexes II and III are the likely sites interacting with cadmium [98]. 

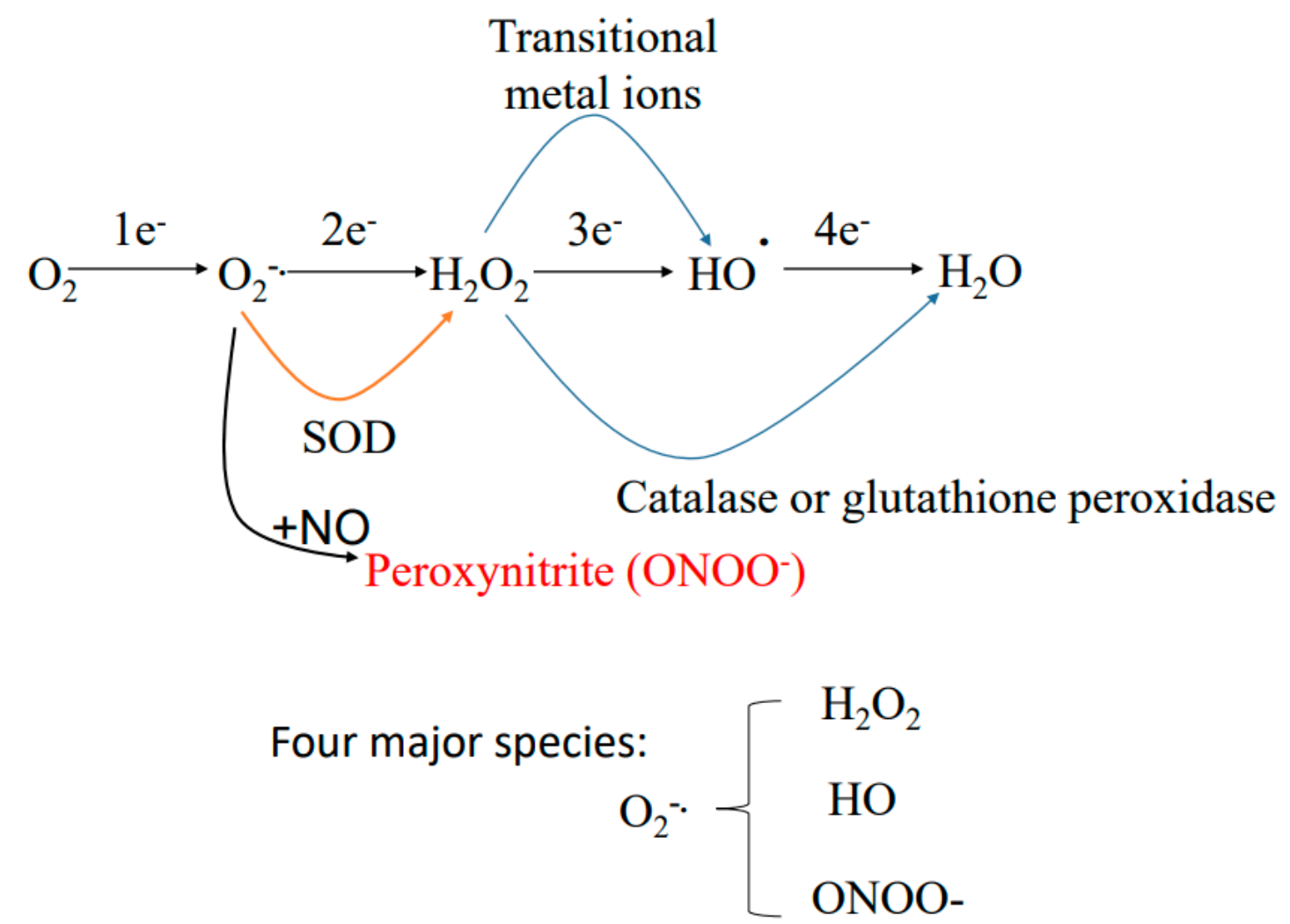

Figure 3. Production of other reactive oxygen species and reactive nitrogen species from the initial species superoxide. Superoxide can be dismutated by superoxide dismutase to form $\mathrm{H}_{2} \mathrm{O}_{2}$, which can be further detoxified by catalase. In the presence of metal ions such as iron, $\mathrm{H}_{2} \mathrm{O}_{2}$ can also generate very reactive species hydroxyl radical. Additionally, superoxide can react with nitric oxide to form peroxynitrite that is also very reactive toward macromolecules.

\subsection{NADPH Oxidase}

NADPH oxidase (NOX) can generate superoxide anion using NADPH as its reducing agent [99]. So far, seven NOXs have been identified (NOX 1-5, Duox1 and DuoX2) [99]. These isoforms differ in many aspects including catalytic oxidase subunit, tissue distribution, intra-cellular location, and mechanisms of regulation [100,101]. All NOXs are composed of multiple subunits. Upon stimulation, these subunits will come together and assemble to form a membrane-associated complex to generate superoxide at the expense of NADPH [102]. Figure 4 shows a representative diagram of NOX assembly upon stimulation whereby the major site of ROS production is the gp91phox subunit with other proteins being the ancillary units required for the regulation and functioning of the whole enzyme complex. It should be noted that Figure 4 only shows the assembly of NOX2. The structural and compositional variations of other NOX isoforms [103] and their potential interaction with cadmium may also play a role in cadmium induced renal toxicity. Under normal conditions, these NOXs function in a beneficial way by regulating kidney metabolism and homeostasis including glucose transport, gluconeogenesis, renal hemodynamics, and electrolyte transport and balance [99]. Under pathophysiological conditions, these NOXs, in particular NOX2 and NOX4 in the kidney, can overgenerate ROS that are damaging to cellular components including DNA, proteins, and lipids, causing cell death and kidney injury $[99,104-106]$. It has been reported that cadmium exposure can increase the expression of NOX1 subunits, leading to increased ROS production from the enzyme [107]. Nevertheless, it is not known exactly which subunit in the NADPH oxidase physically interacts with cadmium at the present time. It should be noted that xanthine oxidase $[108,109]$ and nitric oxide synthase [110-112], although not a major source of ROS in the kidney, may also contribute to renal oxidative stress under a variety of pathological and experimental conditions including cadmium exposure. It should also be pointed out that comprehensive 
evaluations of the roles of NADPH oxidases, xanthine oxidase, and nitric oxide synthase in cadmium-induced kidney injury remain to be conducted.

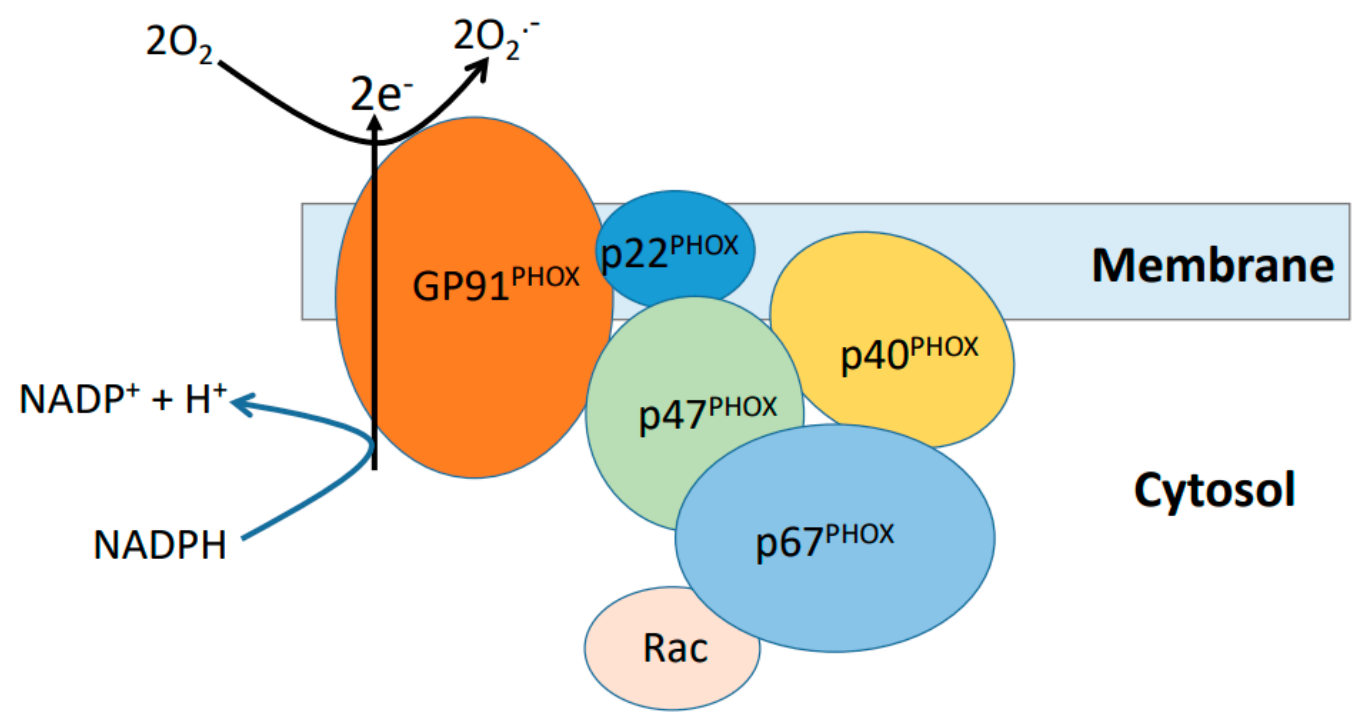

Figure 4. NADPH oxidase assembly and superoxide production at the expense of NADPH. Upon stimulation, each individual subunit of the enzyme is recruited to the membrane and form a membrane-associated complex. Only one subunit GP91 catalyzes partial reduction of oxygen. This figure is adapted from reference [102]. Please not that shown here is NOX2 assembly. For structures and components of other NXO isoforms, please refer reference [103].

\section{Effects of Cadmium on Mitochondrial Function}

Cadmium can enter mitochondria and accumulate therein $[113,114]$. This is likely facilitated by mitochondrial membrane channels, and solute molecule carriers and receptors [114]. Once inside the mitochondria, cadmium can bind thiol-containing proteins and impair the corresponding protein function [80]. Studies have demonstrated that upon exposure to cadmium, kidney mitochondria displayed deformation, swelling, and vaculation, concurrent with increased SOD1 expression and decreased SOD2 and catalase expression [115]. Additionally, the anti-apoptotic protein BCL-2 was also found decreased by cadmium exposure [115]; so was the ratio between reduced glutathione and oxidized glutathione [60]. All these could be a generalized cadmium mitochondrial toxicity and the ultimate outcome would be reflected by overproduction of mitochondrial ROS, disruption of mitochondrial metabolic pathways, and impairment of mitochondrial pores, membrane channels and transporters [80]. It has been reported that complex II and complex III may be the major sites impaired by cadmium in the nephrons [98] while the effects of cadmium on proximal tubular mitochondrial complex I (NADH-ubiquinone oxidoreductase) remain unclear. Disruption of all these processes by cadmium would increase mitochondrial ROS production and eventually lead to cell death and kidney injury [80,114,116-119]. An outline of cadmium induced ROS production, oxidative damage to macromolecules, cell death, and kidney injury is shown in Figure 5, highlighting the concept that oxidative damage is a unifying mechanism of cadmium-induced kidney injury. 


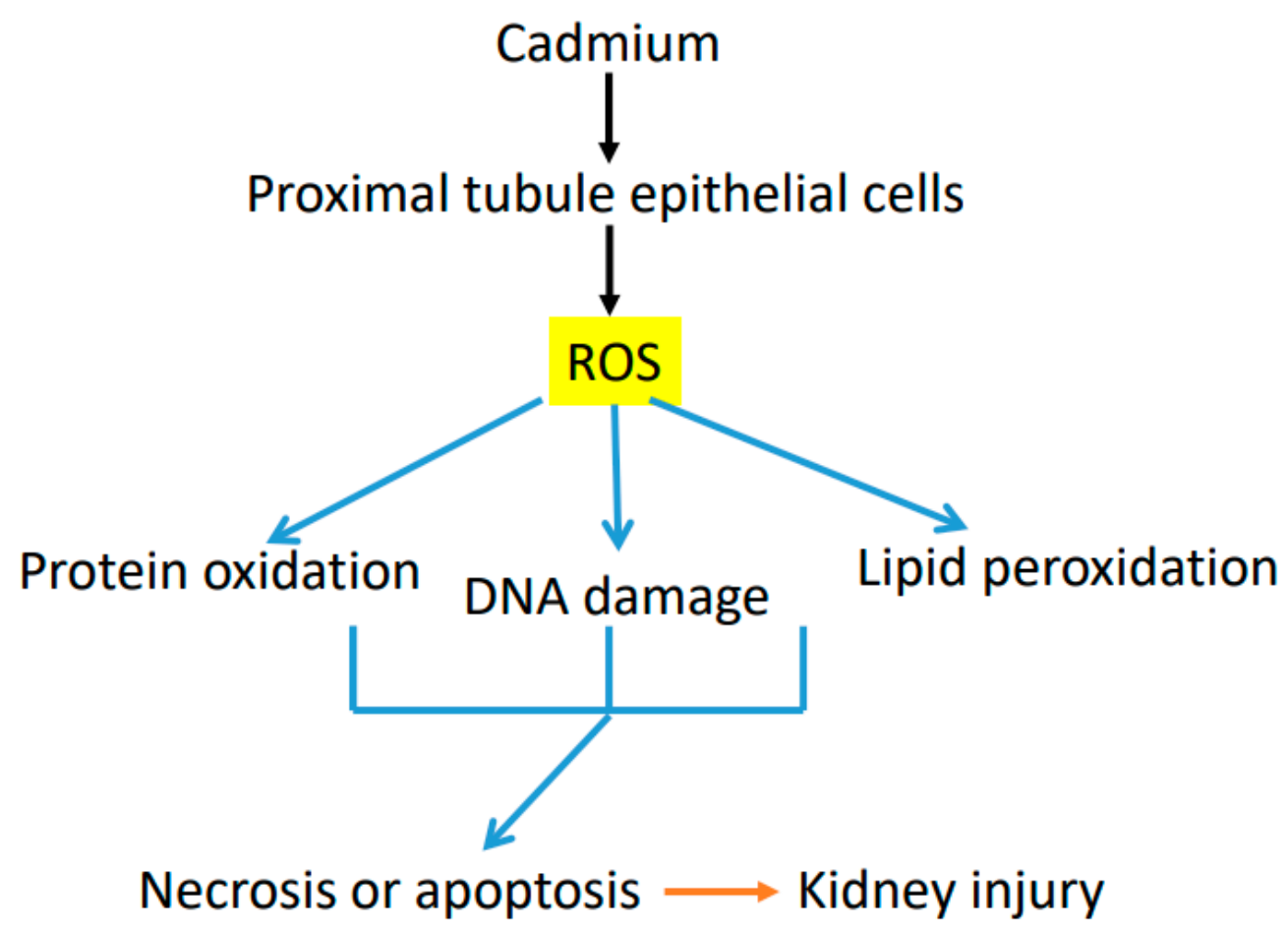

\section{Apoptosis: programed cell death Necrosis: Uncontrolled cell death}

Figure 5. ROS can damage DNA, proteins, and lipids. Damage of the molecules impairs the biological function of each molecule, leading to cell death and kidney injury. Cell death may include both necrosis and apoptosis.

\section{Counteracting Effects of Natural Products, Chemicals and Pharmacological Agents on Cadmium-Induced Kidney Injury}

In further support of the notion that oxidative stress and oxidative damage are the universal mechanisms underlying renal toxicity by cadmium, we herein tabulate evidence that numerous natural products such as plant extracts and herbal medicines have been used to counteract the oxidative, deleterious effects of cadmium on the kidney. Many of these studies used cadmium-induced animal models of kidney injury as a platform [120]. Table 1 selectively shows some of the reported plant extracts and herbs as well as exogenous chemicals and pharmacological agents that can attenuate cadmium-induced oxidative stress involved in kidney injury. Additionally, many of these approaches can also induce the activation of endogenous cellular defense systems such as Nrf2, superoxide dismutase, glutathione peroxidase, and catalase [74,121-124]. Some studies using kidney cell lines such as HEK293 are also included in the table. It should be pointed out that among all the compounds and chemicals listed in Table 1 , it is very difficult to identify which one would be the most efficient in terms of combating confirmed cadmium-induced kidney injury as cross examination and comparison of these natural products on a same platform under exactly the same experimental conditions have not been conducted. In addition, whether administration of these natural antioxidants could increase the efflux of cadmium out of the body remains to be investigated. 
Table 1. Counteracting effects of exogenous compounds such as plant extracts, herbs, chemicals and pharmacological agents on cadmium induced renal toxicity.

\begin{tabular}{|c|c|c|c|}
\hline Plant/Extract/Chemical & Rodent Model & Mechanism & Reference \\
\hline Allium hirtifolium boiss & Rats & Anti-oxidative stress & [125] \\
\hline Apple juice & Rats & Anti-oxidative stress & [126] \\
\hline Arctium lappa & Rats & Anti-oxidative stress & [127] \\
\hline Carnosic acid & Mice and cells & Anti-oxidative damage & [128] \\
\hline Catechin & Rats & Anti-oxidative damage & [129] \\
\hline Caffeic acid phenethyl ester & Rats & Anti-oxidative stress & {$[130,131]$} \\
\hline Chelidonium majus leaves & Rats & Antidiuretic & [132] \\
\hline Chorella pyrenoidosa & Rats & Antihyperglycemic & [133] \\
\hline Cleistocalyx nervosum var. paniala & Rats & Increasing antioxidation power & [134] \\
\hline Coriandrum sativum leaf & Mice & Anti-oxidative stress & [135] \\
\hline Curcumin & Rats & Anti-oxidative stress & [136] \\
\hline Edaravone & Mice/Cells & Inhibiting oxidative stress & [137] \\
\hline Elderberry & Rats & Increasing antioxidant enzymes & [138] \\
\hline Epigallocatechin-3-gallate & Rats & Increasing antioxidant defense & [139] \\
\hline Eucommia ulmoides bark & Rats & Anti-oxidative damage & [140] \\
\hline Ferulic acid & Rats & Anti-oxidative stress & [78] \\
\hline Fragaria ananassa & Rats & Anti-oxidative stress & [141] \\
\hline Ginger & Rats & Decrease lipid peroxidation & [142] \\
\hline Glutathione & Rats & Anti-oxidative stress & [143] \\
\hline Glycyrrhiza glabra & Rats & Anti-oxidative stress & [144] \\
\hline Grape seed procyanidin & Mice & Antioxidants & [145] \\
\hline Grape skin/purple carrot & Rats & Anti-oxidative damage & [146] \\
\hline Green/black/red/white tea & Rats & Anti-oxidative damage & [147] \\
\hline Green olive leaf & Renal cells (MCD4) & Anti-oxidative stress & [148] \\
\hline Herbal adaptogens & Chicken & Anti-oxidative damage & [21] \\
\hline Ipomoea aquatic/Enhydra fluctuans & Mice & Anti-oxidation/anti-apoptosis & [149] \\
\hline Irvingia gabonesis stem bark & Rats & Increasing antioxidant defense & [150] \\
\hline Licorice & Rats & Anti-oxidative damage & {$[151]^{* *}$} \\
\hline Ligustrazine & Rats & Restoring renal function & [152] \\
\hline Lipoic acid & Rats & Anti-apoptosis & {$[68,153]$} \\
\hline Onion/garlic & Rats & Anti-oxidative stress & [154] \\
\hline Origanum majorana $L$. & Rats & Anti-oxidative damage & [155] \\
\hline Persea americana seeds & Rats & Mitigating oxidative stress & [156] \\
\hline Physalis peruviana L & Rats & Anti-oxidation/Anti-apoptosis & [157] \\
\hline Picroliv & Rats & Anti-oxidative stress & [158] \\
\hline Plantamajoside & Rats & Decrease oxidative damage & [159] \\
\hline Pleurotus ostreatus & Rats (female) & Mitigating oxidative damage & [160] \\
\hline Potentilla anserine & Mice and cells & Anti-oxidative stress & [161] \\
\hline Puerarin & Rat proximal tubule cells & Restoring mitochondrial function & [162] \\
\hline Quercetin & Rats & Suppressing ER stress & [163] \\
\hline Resveratrol & Chickens & Anti-oxidative stress & [164] \\
\hline Roflumilast & Rats & Increasing antioxidant defense & [165] \\
\hline Rosmarinic acid & Mice & Anti-oxidative damage & [166] \\
\hline Royal jelly & Mice (male) & Antioxidation/Nrf2 activation & [39] \\
\hline Rutin & Rats & Inhibiting oxidative stress & {$[167]$} \\
\hline Salvia officinalis & Rats & Anti-oxidative damage & [168] \\
\hline Salvia miltiorrhiza & Rats & Anti-oxidative injury & [169] \\
\hline Sana Makki & Rats & Anti-oxidative stress/Nrf2 & [170] \\
\hline Selenium yeast & Chicken & Mitigating necroptosis & {$[171]$} \\
\hline Sesamol & Rats & Inhibiting oxidative stress & [172] \\
\hline SInapic acid & Rats & Inhibiting oxidative stress & [173] \\
\hline Solanum torvum Swartz & Rats & Anti-oxidative stress & {$[174]$} \\
\hline Spinacia oleracea polysaccharides & HEK293 cells & Anti-oxidative stress & [175] \\
\hline Telmisartan & Mice & Suppressing oxidative stress & [176] \\
\hline Tetrahydrobiopterin & Rats & Maintaining mitochondria integrity & [177] \\
\hline Thunbergia laurifolia leaf & Kidney cells & Increasing antioxidant enzymes & [178] \\
\hline
\end{tabular}


Table 1. Cont.

\begin{tabular}{ccccc}
\hline Plant/Extract/Chemical & Rodent Model & Mechanism & Reference \\
\hline Thymus serrulatus essential oil & Rats & Anti-oxidative stress & {$[179]$} \\
Thymoquinone & Rats & Increasing glutathione & {$[180]$} \\
Tinospora cordifolia & Rats & Anti-oxidative stress & {$[181]$} \\
Trehalose & Rats & Inhibiting oxidative stress & {$[182]$} \\
Tribulus terrestris linn & Rats & Anti-oxidation & {$[183]$} \\
Vitamin C & Rabbits & Anti-oxidative stress & {$[184]$} \\
Vitamin E & Rats & Enhancing antioxidant defense & {$[185]$} \\
\hline
\end{tabular}

** Please note that licorice could also pose renal toxicity under certain conditions [186].

\section{Other Potential Interventional Approaches}

In addition to the plant extracts, herbs and pharmacological agents as shown in Table 1, there are other approaches that have also been applied to counteract cadmium-induced kidney injury. For example, caloric restriction as an established interventional approach for aging and age-related diseases [187-190] has been demonstrated to mitigate cadmiuminduced renal toxicity and kidney dysfunction [191]. Dietary restriction of calcium intake has also been shown to enhance cadmium-induced expression of metallothionein, which could minimize cadmium toxicity [192]. The protective effects of preconditioning and postconditioning observed in numerous studies [193-195], if any, elicited by a variety of approaches including ischemia, hypoxia, chemicals or pharmacological agents are yet to be investigated. Additionally, metal chelation using specific chelating agents may also be considered as an interventional approach [196]. Recent findings that persulfide and polysulfide can bind to cadmium thereby decreasing cadmium toxicity [197-199] may also provide potential approaches for counteracting cadmium-induced kidney injury.

\section{Postulated Model of Cadmium-Induced Proximal Tubule Lesion}

Prozialeck and Edwards proposed a model of proximal convoluted tubular cell injury in 2012 [50] that we think elaborates very well the mechanism of cadmium-induced kidney injury in terms of oxidative damage as a unifying mechanism. This model is similar to what has been proposed to explain the mechanisms of ischemic acute kidney injury $[8,10,200,201]$. Essentially, as diagramed in Figure 6, under healthy conditions and in the absence of cadmium deposit and accumulation, epithelial cells in the proximal tubule are closely associated with each other via specialized junctional structures. These epithelial cells align orderly and tightly on the tubular basement membrane via local adhesion molecules to collectively achieve filtration and reabsorption. In the presence of cadmium, which can accumulate in the cytosolic and mitochondrial compartments, cadmium binds thiol-containing proteins and peptides, leading to functional impairment of these cadmium-bound proteins and peptides. Consequently, such impairments cause mitochondrial electron leakage or NADPH oxidase dysfunction, resulting in enhanced production of ROS and elevated levels of oxidative stress. If the oxidative stress is mild, the tubular cells can repair themselves and resume normal function. It should be noted that this self-repair is likely achieved by de-differentiated tubular epithelial cells instead of differentiated and fixed tubular progenitor cells [202,203]. However, if the oxidative stress is severe and overwhelms cellular repair capacity, an irreversible damage process occurs and cells die by means of apoptosis, necrosis or both [204,205], leading to cell-cell and cell-basement membrane dissociations. This would lead to proteinuria, polyuria, and a progressive decline in kidney function. This functional decline, however, may be intervened and halted by the antioxidative approaches shown in Table 1 if applied appropriately. It should be pointed out that in order to distinguish cadmium-induced proteinuria from primary glomerular lesion, the magnitude of proteinuria and a cadmium concentration dependent manner will need to be characterized. 


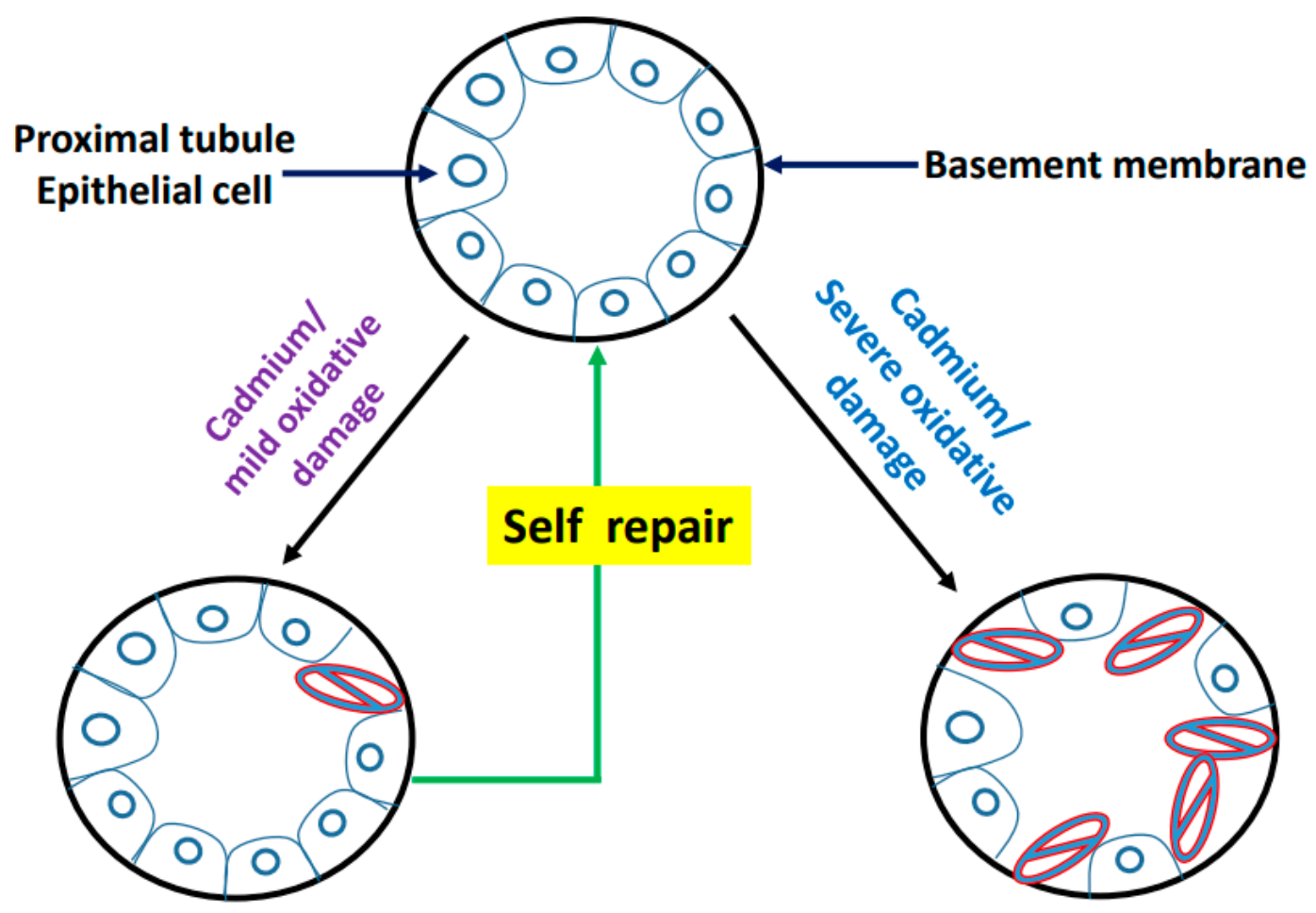

Figure 6. Schematic diagram depicting cadmium-induced injury to proximal tubular epithelial cells. When oxidative damage is mild, the cells can mobilize their repair defense system and self-repair, leading to maintenance of cellular function. When oxidative damage is severe, cells lose their self-repair capacity and die, leading to widespread cell death and kidney injury. (Adapted from reference [50]).

\section{Diagnosis of Cadmium-Induced Kidney Injury}

While diagnosis of cadmium-induced kidney injury is complicated by factors such as dosage of exposure, duration of exposure, early stage injury or late stage irreversible injury as well as whether there does any exist underlying disease, a series of parameters could be combined to indicate whether a kidney injury is caused by cadmium exposure. These parameters include measurements of blood and urine cadmium, urinary metallothionein, urinary $\beta 2$-microglobulin and $N$-acetyl- $\beta$-glucosaminidase. In addition, kidney injury molecule-1 (Kim-1) could also be used to indicate early stage of cadmium-induced proximal tubular injury [50]. Moreover, severe cadmium poisoning could also cause pains in the spine and joints [24]. Collectively, measurements of these biomarkers or indices should provide good evidence that a cadmium-caused kidney injury has occurred. It should be noted that once these biomarkers appear and are detectable, cadmium induced kidney injury might be at an advanced stage that is irreversible. Therefore, novel biomarkers of cadmium-induced early stage kidney injury remain to be explored.

\section{Summary}

Cadmium exposure and cadmium-induced kidney disease are major public health issues. Mitochondria and NADPH oxidase can be impaired by cadmium that accumulates in the proximal tubular site of nephrons, and thus, are the major sources of ROS. Therefore, the main underlying mechanism of cadmium renal toxicity is enhanced oxidative stress and associated damage to DNA, proteins, and lipids, eventually leading to cell death, kidney injury, and decline in kidney function (Figure 5). Given that cadmium exposure is inevitable in the foreseeable future, cadmium-induced animal models of kidney disease should continue to play an important role in investigating the etiological, pathological, pharmacogenetic, pharmacological, and therapeutic aspects of cadmium-induced kidney disorders. Finally, in addition to elucidating the detailed mechanisms of cadmium-caused mitochondrial oxidative stress and redox imbalance, future studies should also explore 
novel biomarkers that can be used to diagnose early kidney injury by cadmium exposure. Moreover, whether administration of natural products such as those listed in Table 1 could increase the efflux of cadmium out of the body remains to be investigated.

Author Contributions: Conceptulization, L.-J.Y.; original draft preparation, L.-J.Y.; review and editing, D.C.A. and L.-J.Y. All authors have read and agreed to the published version of the manuscript.

Funding: This research received no external funding.

Institutional Review Board Statement: Not applicable.

Informed Consent Statement: Not applicable.

Conflicts of Interest: The authors declare no conflict of interest.

\section{References}

1. Koeppen, B.M.; Stanton, B.A. Renal Physiology, 5th ed.; Elsevier: Philadelphia, PA, USA, 2013.

2. Rennke, H.G.; Denker, B.M. Renal Pathology: The Essentials, 5th ed.; Wolters Kluwer: New York, NY, USA, 2020.

3. Dipiro, J.T.; Talbet, R.L.; Yee, G.C.; Matzke, G.R.; Wells, B.G.; Posey, L.M. Pharmacotherapy: A Pathophysiological Approach, 9th ed.; McGraw-Hill Education: New York, NY, USA, 2014.

4. Sumida, K.D.; Garrett, J.H.; McJilton, W.T.; Hevener, A.L.; Donovan, C.M. Effect of endurance training and fasting on renal gluconeogenic enzymes in the rat. Int. J. Sport Nutr. Exerc. Metab. 2004, 14, 323-332. [CrossRef]

5. Kaneko, K.; Soty, M.; Zitoun, C.; Duchampt, A.; Silva, M.; Philippe, E.; Gautier-Stein, A.; Rajas, F.; Mithieux, G. The role of kidney in the inter-organ coordination of endogenous glucose production during fasting. Mol. Metab. 2018, 16, 203-212. [CrossRef]

6. Sharma, R.; Tiwari, S. Renal gluconeogenesis in insulin resistance: A culprit for hyperglycemia in diabetes. World J. Diabetes 2021, 12, 556-568. [CrossRef] [PubMed]

7. Lieberman, M.; Marks, A.D. Marks' Basic Medical Biochemistry: A Clinical Approach, 4th ed.; Wolters Kluwer/Lippincott Williams \& Wilkins: Philadelphia, PA, USA, 2013.

8. Molitoris, B.A.; Marrs, J. The role of cell adhesion molecules in ischemic acute renal failure. Am. J. Med. 1999, 106, 583-592. [CrossRef]

9. Scholz, H.; Boivin, F.J.; Schmidt-Ott, K.M.; Bachmann, S.; Eckardt, K.U.; Scholl, U.I.; Persson, P.B. Kidney physiology and susceptibility to acute kidney injury: Implications for renoprotection. Nat. Rev. Nephrol. 2021, 17, 335-349. [CrossRef]

10. Zhuang, S.; Lu, B.; Daubert, R.A.; Chavin, K.D.; Wang, L.; Schnellmann, R.G. Suramin promotes recovery from renal ischemia/reperfusion injury in mice. Kidney Int. 2009, 75, 304-311. [CrossRef] [PubMed]

11. Tran, M.; Tam, D.; Bardia, A.; Bhasin, M.; Rowe, G.C.; Kher, A.; Zsengeller, Z.K.; Akhavan-Sharif, M.R.; Khankin, E.V.; Saintgeniez, M.; et al. Pgc-1alpha promotes recovery after acute kidney injury during systemic inflammation in mice. J. Clin. Investig. 2011, 121, 4003-4014. [CrossRef]

12. Dare, A.J.; Bolton, E.A.; Pettigrew, G.J.; Bradley, J.A.; Saeb-Parsy, K.; Murphy, M.P. Protection against renal ischemia-reperfusion injury in vivo by the mitochondria targeted antioxidant mitoq. Redox Biol. 2015, 5, 163-168. [CrossRef]

13. Perazella, M.A. Renal vulnerability to drug toxicity. Clin. J. Am. Soc. Nephrol. 2009, 4, 1275-1283. [CrossRef]

14. Cohen, A.; Ioannidis, K.; Ehrlich, A.; Regenbaum, S.; Cohen, M.; Ayyash, M.; Tikva, S.S.; Nahmias, Y. Mechanism and reversal of drug-induced nephrotoxicity on a chip. Sci. Transl. Med. 2021, 13, eabd6299. [CrossRef]

15. Hosohata, K. Role of oxidative stress in drug-induced kidney injury. Int. J. Mol. Sci. 2016, 17, 1826. [CrossRef] [PubMed]

16. Osman, A.T.; Sharkawi, S.M.Z.; Hassan, M.I.A.; Abo-Youssef, A.M.; Hemeida, R.A.M. Empagli fl ozin and neohesperidin protect against methotrexate-induced renal toxicity via suppression of oxidative stress and inflammation in male rats. Food Chem. Toxicol. 2021, 155, 112406. [CrossRef] [PubMed]

17. Haider, L.; Sharif, S.; Hasan, A.; McFarlane, I.M. Low-dose methotrexate toxicity in the setting of vancomycin-induced acute kidney injury. Am. J. Med. Case Rep. 2020, 8, 206-209. [CrossRef] [PubMed]

18. Hall, A.M.; Trepiccione, F.; Unwin, R.J. Drug toxicity in the proximal tubule: New models, methods and mechanisms. Pediatr. Nephrol. 2021. [CrossRef] [PubMed]

19. Wen, J.; Zeng, M.; Shu, Y.; Guo, D.; Sun, Y.; Guo, Z.; Wang, Y.; Liu, Z.; Zhou, H.; Zhang, W. Aging increases the susceptibility of cisplatin-induced nephrotoxicity. Age 2015, 37, 112. [CrossRef]

20. Lash, L.H. Diverse roles of mitochondria in renal injury from environmental toxicants and therapeutic drugs. Int. J. Mol. Sci. 2021, 22, 4172. [CrossRef]

21. Bharavi, K.; Reddy, A.G.; Rao, G.S.; Reddy, A.R.; Rao, S.V. Reversal of cadmium-induced oxidative stress in chicken by herbal adaptogens withania somnifera and ocimum sanctum. Toxicol. Int. 2010, 17, 59-63. [CrossRef]

22. Kataria, A.; Trasande, L.; Trachtman, H. The effects of environmental chemicals on renal function. Nat. Rev. Nephrol. 2015, 11, 610-625. [CrossRef]

23. Johri, N.; Jacquillet, G.; Unwin, R. Heavy metal poisoning: The effects of cadmium on the kidney. Biometals 2010, $23,783-792$. [CrossRef] 
24. Vervaet, B.A.; D’Haese, P.C.; Verhulst, A. Environmental toxin-induced acute kidney injury. Clin. Kidney J. 2017, 10, 747-758. [CrossRef]

25. Rizwan, S.; Naqshbandi, A.; Farooqui, Z.; Khan, A.A.; Khan, F. Protective effect of dietary flaxseed oil on arsenic-induced nephrotoxicity and oxidative damage in rat kidney. Food Chem. Toxicol. 2014, 68, 99-107. [CrossRef]

26. Kimura, A.; Ishida, Y.; Hayashi, T.; Wada, T.; Yokoyama, H.; Sugaya, T.; Mukaida, N.; Kondo, T. Interferon-gamma plays protective roles in sodium arsenite-induced renal injury by up-regulating intrarenal multidrug resistance-associated protein 1 expression. Am. J. Pathol. 2006, 169, 1118-1128. [CrossRef] [PubMed]

27. Barregard, L.; Bergstrom, G.; Fagerberg, B. Cadmium, type 2 diabetes, and kidney damage in a cohort of middle-aged women. Environ. Res. 2014, 135, 311-316. [CrossRef] [PubMed]

28. Gangadhariah, M.H.; Luther, J.M.; Garcia, V.; Paueksakon, P.; Zhang, M.Z.; Hayward, S.W.; Love, H.D.; Falck, J.R.; Manthati, V.L.; Imig, J.D.; et al. Hypertension is a major contributor to 20-hydroxyeicosatetraenoic acid-mediated kidney injury in diabetic nephropathy. J. Am. Soc. Nephrol. 2015, 26, 597-610. [CrossRef] [PubMed]

29. Wang, Z.; do Carmo, J.M.; da Silva, A.A.; Fu, Y.; Hall, J.E. Mechanisms of synergistic interactions of diabetes and hypertension in chronic kidney disease: Role of mitochondrial dysfunction and er stress. Curr. Hypertens Rep. 2020, 22, 15. [CrossRef] [PubMed]

30. Ware, K.; Yildiz, V.; Xiao, M.; Medipally, A.; Hemminger, J.; Scarl, R.; Satoskar, A.A.; Hebert, L.; Ivanov, I.; Biederman, L.; et al. Hypertension and the kidney: Reduced kidney mass is bad for both normotensive and hypertensive rats. Am. J. Hypertens 2021. [CrossRef] [PubMed]

31. Narsipur, S.S.; Peterson, O.W.; Smith, R.; Bigby, T.D.; Parthasarathy, S.; Gabbai, F.B.; Wilson, C.B.; Blantz, R.C. Mechanisms of glomerular immune injury: Effects of antioxidant treatment. J. Am. Soc. Nephrol. 2003, 14, 1748-1755. [CrossRef]

32. Duann, P.; Lianos, E.A. Mechanisms of ho-1 mediated attenuation of renal immune injury: A gene profiling study. Transl. Res. 2011, 158, 249-261. [CrossRef]

33. Persson, F.; Rossing, P. Diagnosis of diabetic kidney disease: State of the art and future perspective. Kidney Int. Suppl. 2018, 8, 2-7. [CrossRef]

34. Hallan, S.; Sharma, K. The role of mitochondria in diabetic kidney disease. Curr. Diabetes Rep. 2016, 16, 61. [CrossRef] [PubMed]

35. Wei, P.Z.; Szeto, C.C. Mitochondrial dysfunction in diabetic kidney disease. Clin. Chim. Acta 2019, 496, 108-116. [CrossRef]

36. Yan, L.J. Nadh/nad(+) redox imbalance and diabetic kidney disease. Biomolecules 2021, 11, 730. [CrossRef]

37. Orr, S.E.; Bridges, C.C. Chronic kidney disease and exposure to nephrotoxic metals. Int. J. Mol. Sci. 2017, 18, 1039. [CrossRef]

38. Edwards, J.R.; Prozialeck, W.C. Cadmium, diabetes and chronic kidney disease. Toxicol. Appl. Pharmacol. 2009, 238, 289-293. [CrossRef]

39. Almeer, R.S.; AlBasher, G.I.; Alarifi, S.; Alkahtani, S.; Ali, D.; Abdel Moneim, A.E. Royal jelly attenuates cadmium-induced nephrotoxicity in male mice. Sci. Rep. 2019, 9, 5825. [CrossRef]

40. Almeer, R.S.; Kassab, R.B.; AlBasher, G.I.; Alarifi, S.; Alkahtani, S.; Ali, D.; Abdel Moneim, A.E. Royal jelly mitigates cadmiuminduced neuronal damage in mouse cortex. Mol. Biol. Rep. 2019, 46, 119-131. [CrossRef] [PubMed]

41. Aurisano, N.; Huang, L.; Mila, I.C.L.; Jolliet, O.; Fantke, P. Chemicals of concern in plastic toys. Environ. Int. 2021, 146, 106194. [CrossRef] [PubMed]

42. Chen, C.; Han, X.; Wang, G.; Liu, D.; Bao, L.; Jiao, C.; Luan, J.; Hou, Y.; Xu, Y.; Wang, H.; et al. Nrf2 deficiency aggravates the kidney injury induced by subacute cadmium exposure in mice. Arch. Toxicol. 2021, 95, 883-893. [CrossRef] [PubMed]

43. Satarug, S.; Nishijo, M.; Lasker, J.M.; Edwards, R.J.; Moore, M.R. Kidney dysfunction and hypertension: Role for cadmium, p450 and heme oxygenases? Tohoku J. Exp. Med. 2006, 208, 179-202. [CrossRef] [PubMed]

44. Hao, R.; Song, X.; Sun-Waterhouse, D.; Tan, X.; Li, F.; Li, D. Mir-34a/sirt1/p53 signaling pathway contributes to cadmium-induced nephrotoxicity: A preclinical study in mice. Environ. Pollut 2021, 282, 117029. [CrossRef]

45. Kim, K.S.; Lim, H.J.; Lim, J.S.; Son, J.Y.; Lee, J.; Lee, B.M.; Chang, S.C.; Kim, H.S. Curcumin ameliorates cadmium-induced nephrotoxicity in sprague-dawley rats. Food Chem. Toxicol. 2018, 114, 34-40. [CrossRef]

46. Tripathi, S.; Srivastav, A.K. Cytoarchitectural alterations in kidney of wistar rat after oral exposure to cadmium chloride. Tissue Cell 2011, 43, 131-136. [CrossRef]

47. Rikans, L.E.; Yamano, T. Mechanisms of cadmium-mediated acute hepatotoxicity. J. Biochem. Mol. Toxicol. 2000, 14, 110-117. [CrossRef]

48. Kim, S.C.; Cho, M.K.; Kim, S.G. Cadmium-induced non-apoptotic cell death mediated by oxidative stress under the condition of sulfhydryl deficiency. Toxicol. Lett. 2003, 144, 325-336. [CrossRef]

49. Godt, J.; Scheidig, F.; Grosse-Siestrup, C.; Esche, V.; Brandenburg, P.; Reich, A.; Groneberg, D.A. The toxicity of cadmium and resulting hazards for human health. J. Occup. Med. Toxicol. 2006, 1, 22. [CrossRef] [PubMed]

50. Prozialeck, W.C.; Edwards, J.R. Mechanisms of cadmium-induced proximal tubule injury: New insights with implications for biomonitoring and therapeutic interventions. J. Pharmacol. Exp. Ther. 2012, 343, 2-12. [CrossRef] [PubMed]

51. Prozialeck, W.C.; Vaidya, V.S.; Liu, J.; Waalkes, M.P.; Edwards, J.R.; Lamar, P.C.; Bernard, A.M.; Dumont, X.; Bonventre, J.V. Kidney injury molecule-1 is an early biomarker of cadmium nephrotoxicity. Kidney Int. 2007, 72, 985-993. [CrossRef]

52. Shaikh, Z.A.; Lucis, O.J. Cadmium and zinc binding in mammalian liver and kidneys. Arch. Environ. Health 1972, $24,419-425$. [CrossRef]

53. Shaikh, Z.A.; Lucis, O.J. Biological differences in cadmium and zinc turnover. Arch. Environ. Health 1972, 24, 410-418. [CrossRef] 
54. Liu, J.; Liu, Y.; Habeebu, S.S.; Klaassen, C.D. Susceptibility of mt-null mice to chronic cdcl2-induced nephrotoxicity indicates that renal injury is not mediated by the cdmt complex. Toxicol. Sci. 1998, 46, 197-203.

55. Klaassen, C.D.; Liu, J. Role of metallothionein in cadmium-induced hepatotoxicity and nephrotoxicity. Drug Metab. Rev. 1997, 29, 79-102. [CrossRef]

56. Nomiyama, K.; Nomiyama, H. Tissue metallothioneins in rabbits chronically exposed to cadmium, with special reference to the critical concentration of cadmium in the renal cortex. Dev. Toxicol. Environ. Sci. 1982, 9, 47-67. [PubMed]

57. Nomiyama, K.; Nomiyama, H. Critical concentration of 'unbound' cadmium in the rabbit renal cortex. Experientia 1986, $42,149$. [CrossRef] [PubMed]

58. Prozialeck, W.C.; Edwards, J.R.; Lamar, P.C.; Liu, J.; Vaidya, V.S.; Bonventre, J.V. Expression of kidney injury molecule-1 (kim-1) in relation to necrosis and apoptosis during the early stages of cd-induced proximal tubule injury. Toxicol. Appl. Pharmacol. 2009, 238, 306-314. [CrossRef] [PubMed]

59. Fels, J.; Scharner, B.; Zarbock, R.; Zavala Guevara, I.P.; Lee, W.K.; Barbier, O.C.; Thevenod, F. Cadmium complexed with beta2-microglubulin, albumin and lipocalin-2 rather than metallothionein cause megalin:Cubilin dependent toxicity of the renal proximal tubule. Int. J. Mol. Sci. 2019, 20, 2379. [CrossRef] [PubMed]

60. Nair, A.R.; Lee, W.K.; Smeets, K.; Swennen, Q.; Sanchez, A.; Thevenod, F.; Cuypers, A. Glutathione and mitochondria determine acute defense responses and adaptive processes in cadmium-induced oxidative stress and toxicity of the kidney. Arch. Toxicol. 2015, 89, 2273-2289. [CrossRef]

61. Bagchi, D.; Bagchi, M.; Hassoun, E.A.; Stohs, S.J. Cadmium-induced excretion of urinary lipid metabolites, DNA damage, glutathione depletion, and hepatic lipid peroxidation in sprague-dawley rats. Biol. Trace Elem. Res. 1996, 52, 143-154. [CrossRef]

62. Hassoun, E.A.; Stohs, S.J. Cadmium-induced production of superoxide anion and nitric oxide, DNA single strand breaks and lactate dehydrogenase leakage in j774a.1 cell cultures. Toxicology 1996, 112, 219-226. [CrossRef]

63. Sotomayor, C.G.; Groothof, D.; Vodegel, J.J.; Eisenga, M.F.; Knobbe, T.J.; IJmker, J.; Lammerts, R.G.M.; de Borst, M.H.; Berger, S.P.; Nolte, I.M.; et al. Plasma cadmium is associated with increased risk of long-term kidney graft failure. Kidney Int. 2021, 99, 1213-1224. [CrossRef]

64. Fransson, M.N.; Barregard, L.; Sallsten, G.; Akerstrom, M.; Johanson, G. Physiologically-based toxicokinetic model for cadmium using markov-chain monte carlo analysis of concentrations in blood, urine, and kidney cortex from living kidney donors. Toxicol. Sci. 2014, 141, 365-376. [CrossRef]

65. Jarup, L. Cadmium overload and toxicity. Nephrol. Dial. Transplant. 2002, 17, 35-39. [CrossRef]

66. Jarup, L.; Persson, B.; Elinder, C.G. Decreased glomerular filtration rate in solderers exposed to cadmium. Occup. Environ. Med. 1995, 52, 818-822. [CrossRef]

67. Kazantzis, G. Renal tubular dysfunction and abnormalities of calcium metabolism in cadmium workers. Environ. Health Perspect. 1979, 28, 155-159. [CrossRef]

68. Chen, S.; Liu, G.; Long, M.; Zou, H.; Cui, H. Alpha lipoic acid attenuates cadmium-induced nephrotoxicity via the mitochondrial apoptotic pathways in rat. J. Inorg. Biochem. 2018, 184, 19-26. [CrossRef]

69. Prozialeck, W.C.; Edwards, J.R.; Vaidya, V.S.; Bonventre, J.V. Preclinical evaluation of novel urinary biomarkers of cadmium nephrotoxicity. Toxicol. Appl. Pharmacol. 2009, 238, 301-305. [CrossRef]

70. Sarma, S.N.; Saleem, A.; Lee, J.Y.; Tokumoto, M.; Hwang, G.W.; Man Chan, H.; Satoh, M. Effects of long-term cadmium exposure on urinary metabolite profiles in mice. J. Toxicol. Sci. 2018, 43, 89-100. [CrossRef] [PubMed]

71. Porter, G.A. Risk factors for toxic nephropathies. Toxicol. Lett. 1989, 46, 269-279. [CrossRef]

72. Nath, R.; Prasad, R.; Palinal, V.K.; Chopra, R.K. Molecular basis of cadmium toxicity. Prog. Food Nutr. Sci. 1984, 8, $109-163$.

73. Gong, P.; Wang, M.; Yang, W.; Chang, X.; Wang, L.; Chen, F. Integrated metabolomics coupled with pattern recognition and pathway analysis to reveal molecular mechanism of cadmium-induced diabetic nephropathy. Toxicol. Res. 2021, 10, 777-791. [CrossRef]

74. Gong, P.; Chang, X.; Chen, X.; Bai, X.; Wen, H.; Pi, S.; Yang, W.; Wang, L.; Chen, F. Metabolomics study of cadmium-induced diabetic nephropathy and protective effect of caffeic acid phenethyl ester using uplc-q-tof-ms combined with pattern recognition. Environ. Toxicol. Pharmacol. 2017, 54, 80-92. [CrossRef] [PubMed]

75. Zhou, B.; Gentry, A.; Xu, Q.; Young, J.L.; Yan, X.; Pagidas, K.; Yang, Y.; Watson, W.H.; Kong, M.; Cai, L.; et al. Effects of cadmium and high-fat diet on essential metal concentration in the mouse testis. Toxicol. Rep. 2021, 8, 718-723. [CrossRef] [PubMed]

76. Hagedoorn, I.J.M.; Gant, C.M.; Huizen, S.V.; Maatman, R.; Navis, G.; Bakker, S.J.L.; Laverman, G.D. Lifestyle-related exposure to cadmium and lead is associated with diabetic kidney disease. J. Clin. Med. 2020, 9, 2432. [CrossRef] [PubMed]

77. Shah, S.; Iqbal, M.; Karam, J.; Salifu, M.; McFarlane, S.I. Oxidative stress, glucose metabolism, and the prevention of type 2 diabetes: Pathophysiological insights. Antioxid. Redox Signal. 2007, 9, 911-929. [CrossRef] [PubMed]

78. Sanjeev, S.; Bidanchi, R.M.; Murthy, M.K.; Gurusubramanian, G.; Roy, V.K. Influence of ferulic acid consumption in ameliorating the cadmium-induced liver and renal oxidative damage in rats. Environ. Sci Pollut Res. Int. 2019, 26, 20631-20653. [CrossRef] [PubMed]

79. Zhang, H.; Reynolds, M. Cadmium exposure in living organisms: A short review. Sci. Total Environ. 2019, 678, 761-767. [CrossRef]

80. Cannino, G.; Ferruggia, E.; Luparello, C.; Rinaldi, A.M. Cadmium and mitochondria. Mitochondrion 2009, 9, 377-384. [CrossRef]

81. Genchi, G.; Sinicropi, M.S.; Lauria, G.; Carocci, A.; Catalano, A. The effects of cadmium toxicity. Int. J. Environ. Res. Public Health 2020, 17, 3782. [CrossRef] [PubMed] 
82. Murphy, M.P. How mitochondria produce reactive oxygen species. Biochem. J. 2009, 417, 1-13. [CrossRef]

83. Rosca, M.G.; Vazquez, E.J.; Chen, Q.; Kerner, J.; Kern, T.S.; Hoppel, C.L. Oxidation of fatty acids is the source of increased mitochondrial reactive oxygen species production in kidney cortical tubules in early diabetes. Diabetes 2012, 61, 2074-2083. [CrossRef]

84. Sena, L.A.; Chandel, N.S. Physiological roles of mitochondrial reactive oxygen species. Mol. Cell 2012, 48, 158-167. [CrossRef]

85. Bhargava, P.; Schnellmann, R.G. Mitochondrial energetics in the kidney. Nat. Rev. Nephrol. 2017, 13, 629-646. [CrossRef] [PubMed]

86. Trewin, A.J.; Bahr, L.L.; Almast, A.; Berry, B.J.; Wei, A.Y.; Foster, T.H.; Wojtovich, A.P. Mitochondrial reactive oxygen species generated at the complex-ii matrix or intermembrane space microdomain have distinct effects on redox signaling and stress sensitivity in caenorhabditis elegans. Antioxid. Redox Signal. 2019, 31, 594-607. [CrossRef]

87. Ralph, S.J.; Moreno-Sanchez, R.; Neuzil, J.; Rodriguez-Enriquez, S. Inhibitors of succinate: Quinone reductase/complex ii regulate production of mitochondrial reactive oxygen species and protect normal cells from ischemic damage but induce specific cancer cell death. Pharm. Res. 2011, 28, 2695-2730. [CrossRef] [PubMed]

88. Brand, M.D. Riding the tiger-Physiological and pathological effects of superoxide and hydrogen peroxide generated in the mitochondrial matrix. Crit. Rev. Biochem. Mol. Biol. 2020, 55, 592-661. [CrossRef]

89. Brand, M.D.; Goncalves, R.L.; Orr, A.L.; Vargas, L.; Gerencser, A.A.; Borch Jensen, M.; Wang, Y.T.; Melov, S.; Turk, C.N.; Matzen, J.T.; et al. Suppressors of superoxide-h2o2 production at site iq of mitochondrial complex i protect against stem cell hyperplasia and ischemia-reperfusion injury. Cell Metab. 2016, 24, 582-592. [CrossRef]

90. Ames, B.N.; Shigenaga, M.K. Oxidants are a major contributor to aging. Ann. N. Y. Acad. Sci. 1992, 663, 85-96. [CrossRef]

91. Yan, L.J. Pathogenesis of chronic hyperglycemia: From reductive stress to oxidative stress. J. Diabetes Res. 2014, $2014,137919$. [CrossRef]

92. Salvemini, D.; Doyle, T.M.; Cuzzocrea, S. Superoxide, peroxynitrite and oxidative/nitrative stress in inflammation. Biochem. Soc. Trans. 2006, 34, 965-970. [CrossRef]

93. Kassab, A.; Piwowar, A. Cell oxidant stress delivery and cell dysfunction onset in type 2 diabetes. Biochimie 2012, 94, 1837-1848. [CrossRef] [PubMed]

94. Klivenyi, P.; Starkov, A.A.; Calingasan, N.Y.; Gardian, G.; Browne, S.E.; Yang, L.; Bubber, P.; Gibson, G.E.; Patel, M.S.; Beal, M.F Mice deficient in dihydrolipoamide dehydrogenase show increased vulnerability to mptp, malonate and 3-nitropropionic acid neurotoxicity. J. Neurochem. 2004, 88, 1352-1360. [CrossRef] [PubMed]

95. Vaubel, R.A.; Rustin, P.; Isaya, G. Mutations in the dimer interface of dihydrolipoamide dehydrogenase promote site-specific oxidative damages in yeast and human cells. J. Biol. Chem. 2011, 286, 40232-40245. [CrossRef]

96. Ambrus, A.; Torocsik, B.; Tretter, L.; Ozohanics, O.; Adam-Vizi, V. Stimulation of reactive oxygen species generation by diseasecausing mutations of lipoamide dehydrogenase. Hum. Mol. Genet. 2011, 20, 2984-2995. [CrossRef]

97. Bunik, V.I.; Brand, M.D. Generation of superoxide and hydrogen peroxide by side reactions of mitochondrial 2-oxoacid dehydrogenase complexes in isolation and in cells. Biol. Chem. 2018, 399, 407-420. [CrossRef]

98. Wang, Y.; Fang, J.; Leonard, S.S.; Rao, K.M. Cadmium inhibits the electron transfer chain and induces reactive oxygen species. Free Radic. Biol. Med. 2004, 36, 1434-1443. [CrossRef]

99. Sedeek, M.; Nasrallah, R.; Touyz, R.M.; Hebert, R.L. Nadph oxidases, reactive oxygen species, and the kidney: Friend and foe. J. Am. Soc. Nephrol. 2013, 24, 1512-1518. [CrossRef]

100. Suh, Y.A.; Arnold, R.S.; Lassegue, B.; Shi, J.; Xu, X.; Sorescu, D.; Chung, A.B.; Griendling, K.K.; Lambeth, J.D. Cell transformation by the superoxide-generating oxidase mox1. Nature 1999, 401, 79-82. [CrossRef] [PubMed]

101. Cheng, G.; Cao, Z.; Xu, X.; van Meir, E.G.; Lambeth, J.D. Homologs of gp91phox: Cloning and tissue expression of nox3, nox4, and nox5. Gene 2001, 269, 131-140. [CrossRef]

102. Gardiner, G.J.; Deffit, S.N.; McLetchie, S.; Perez, L.; Walline, C.C.; Blum, J.S. A role for nadph oxidase in antigen presentation. Front. Immunol 2013, 4, 295. [CrossRef]

103. Drummond, G.R.; Selemidis, S.; Griendling, K.K.; Sobey, C.G. Combating oxidative stress in vascular disease: Nadph oxidases as therapeutic targets. Nat. Rev. Drug Discov. 2011, 10, 453-471. [CrossRef] [PubMed]

104. Cho, S.; Yu, S.L.; Kang, J.; Jeong, B.Y.; Lee, H.Y.; Park, C.G.; Yu, Y.B.; Jin, D.C.; Hwang, W.M.; Yun, S.R.; et al. Nadph oxidase 4 mediates tgf-beta1/smad signaling pathway induced acute kidney injury in hypoxia. PLoS ONE 2019, 14, e0219483.

105. Liu, Q.; Liang, X.; Liang, M.; Qin, R.; Qin, F.; Wang, X. Ellagic acid ameliorates renal ischemic-reperfusion injury through nox4/jak/stat signaling pathway. Inflammation 2020, 43, 298-309. [CrossRef]

106. Lima, N.K.S.; Farias, W.R.A.; Cirilo, M.A.S.; Oliveira, A.G.; Farias, J.S.; Aires, R.S.; Muzi-Filho, H.; Paixao, A.D.O.; Vieira, L.D. Renal ischemia-reperfusion leads to hypertension and changes in proximal tubule na $(+)$ transport and renin-angiotensinaldosterone system: Role of nadph oxidase. Life Sci. 2021, 266, 118879. [CrossRef]

107. Pinheiro Junior, J.E.G.; Moraes, P.Z.; Rodriguez, M.D.; Simoes, M.R.; Cibin, F.; Pinton, S.; Barbosa Junior, F.; Pecanha, F.M.; Vassallo, D.V.; Miguel, M.; et al. Cadmium exposure activates nadph oxidase, renin-angiotensin system and cyclooxygenase 2 pathways in arteries, inducing hypertension and vascular damage. Toxicol. Lett. 2020, 333, 80-89. [CrossRef]

108. Asagba, S.O. Alteration in the activity of oxidative enzymes in the tissues of male wistar albino rats exposed to cadmium. Int. J. Occup. Med. Environ. Health 2010, 23, 55-62. [CrossRef] [PubMed]

109. Greene, E.L.; Paller, M.S. Xanthine oxidase produces o2-. In posthypoxic injury of renal epithelial cells. Am. J. Physiol. 1992, 263, F251-F255. [CrossRef] [PubMed] 
110. Ratliff, B.B.; Abdulmahdi, W.; Pawar, R.; Wolin, M.S. Oxidant mechanisms in renal injury and disease. Antioxid. Redox Signal. 2016, 25, 119-146. [CrossRef]

111. Noris, M.; Remuzzi, G. Physiology and pathophysiology of nitric oxide in chronic renal disease. Proc. Assoc. Am. Physicians 1999, 111, 602-610. [CrossRef]

112. Soyupek, S.; Oksay, T.; Sutcu, R.; Armagan, A.; Gokalp, O.; Perk, H.; Delibas, N. The effect of cadmium toxicity on renal nitric oxide synthase isoenzymes. Toxicol. Ind. Health 2012, 28, 624-628. [CrossRef] [PubMed]

113. Pavon, N.; Buelna-Chontal, M.; Macias-Lopez, A.; Correa, F.; Uribe-Alvarez, C.; Hernandez-Esquivel, L.; Chavez, E. On the oxidative damage by cadmium to kidney mitochondrial functions. Biochem. Cell Biol. 2019, 97, 187-192. [CrossRef]

114. Thevenod, F.; Lee, W.K.; Garrick, M.D. Iron and cadmium entry into renal mitochondria: Physiological and toxicological implications. Front. Cell Dev. Biol 2020, 8, 848. [CrossRef]

115. Liu, Q.; Zhang, R.; Wang, X.; Shen, X.; Wang, P.; Sun, N.; Li, X.; Li, X.; Hai, C. Effects of sub-chronic, low-dose cadmium exposure on kidney damage and potential mechanisms. Ann. Transl. Med. 2019, 7, 177. [CrossRef]

116. Ghasemi, H.; Postampour, F.; Ranjbar, A. The role of oxidative stress in metals toxicity/mitochondrial dysfunction as a key player. GMJ 2014, 3, 2-13.

117. Barnett, L.M.A.; Cummings, B.S. Nephrotoxicity and renal pathophysiology: A contemporary perspective. Toxicol. Sci. 2018, 164, 379-390. [CrossRef] [PubMed]

118. Gobe, G.; Crane, D. Mitochondria, reactive oxygen species and cadmium toxicity in the kidney. Toxicol. Lett. 2010, 198, 49-55. [CrossRef]

119. Ge, J.; Zhang, C.; Sun, Y.C.; Zhang, Q.; Lv, M.W.; Guo, K.; Li, J.L. Cadmium exposure triggers mitochondrial dysfunction and oxidative stress in chicken (Gallus gallus) kidney via mitochondrial upr inhibition and nrf2-mediated antioxidant defense activation. Sci. Total Environ. 2019, 689, 1160-1171. [CrossRef] [PubMed]

120. Sandbichler, A.M.; Hockner, M. Cadmium protection strategies-A hidden trade-off? Int. J. Mol. Sci 2016, 17, 139. [CrossRef]

121. Li, X.; Zhang, H.; Sun, F. Cdse/zns quantum dots exhibited nephrotoxicity through mediating oxidative damage and inflammatory response. Aging 2020, 13, 12194-12206. [CrossRef]

122. Wang, X.Y.; Wang, Z.Y.; Zhu, Y.S.; Zhu, S.M.; Fan, R.F.; Wang, L. Alleviation of cadmium-induced oxidative stress by trehalose via inhibiting the nrf2-keap1 signaling pathway in primary rat proximal tubular cells. J. Biochem. Mol. Toxicol. 2018, 32 , e22011. [CrossRef]

123. Ashrafizadeh, M.; Ahmadi, Z.; Farkhondeh, T.; Samarghandian, S. Back to nucleus: Combating with cadmium toxicity using nrf2 signaling pathway as a promising therapeutic target. Biol. Trace Elem. Res. 2020, 197, 52-62. [CrossRef] [PubMed]

124. Choudhury, C.; Mazumder, R.; Kumar, R.; Dhar, B.; Sengupta, M. Cadmium induced oxystress alters nrf2-keap1 signaling and triggers apoptosis in piscine head kidney macrophages. Aquat. Toxicol. 2021, 231, 105739. [CrossRef] [PubMed]

125. Dastan, D.; Karimi, S.; Larki-Harchegani, A.; Nili-Ahmadabadi, A. Protective effects of allium hirtifolium boiss extract on cadmium-induced renal failure in rats. Environ. Sci. Pollut. Res. Int. 2019, 26, 18886-18892. [CrossRef] [PubMed]

126. Handan, B.A.; De Moura, C.F.G.; Cardoso, C.M.; Santamarina, A.B.; Pisani, L.P.; Ribeiro, D.A. Protective effect of grape and apple juices against cadmium intoxication in the kidney of rats. Drug Res. 2020, 70, 503-511. [CrossRef] [PubMed]

127. Suliman Al-Gebaly, A. Ameliorative effect of arctium lappa against cadmium genotoxicity and histopathology in kidney of wistar rat. Pak. J. Biol. Sci 2017, 20, 314-319. [CrossRef] [PubMed]

128. Das, S.; Dewanjee, S.; Dua, T.K.; Joardar, S.; Chakraborty, P.; Bhowmick, S.; Saha, A.; Bhattacharjee, S.; De Feo, V. Carnosic acid attenuates cadmium induced nephrotoxicity by inhibiting oxidative stress, promoting nrf2/ho- 1 signalling and impairing tgf-beta1/smad/collagen iv signalling. Molecules 2019, 24, 4176. [CrossRef] [PubMed]

129. Wongmekiat, O.; Peerapanyasut, W.; Kobroob, A. Catechin supplementation prevents kidney damage in rats repeatedly exposed to cadmium through mitochondrial protection. Naunyn. Schmiedebergs Arch. Pharmacol. 2018, 391, 385-394. [CrossRef] [PubMed]

130. Gong, P.; Chen, F.; Liu, X.; Gong, X.; Wang, J.; Ma, Y. Protective effect of caffeic acid phenethyl ester against cadmium-induced renal damage in mice. J. Toxicol. Sci. 2012, 37, 415-425. [CrossRef] [PubMed]

131. Kobroob, A.; Chattipakorn, N.; Wongmekiat, O. Caffeic acid phenethyl ester ameliorates cadmium-induced kidney mitochondrial injury. Chem. Biol. Interact. 2012, 200, 21-27. [CrossRef]

132. Koriem, K.M.; Arbid, M.S.; Asaad, G.F. Chelidonium majus leaves methanol extract and its chelidonine alkaloid ingredient reduce cadmium-induced nephrotoxicity in rats. J. Nat. Med. 2013, 67, 159-167. [CrossRef] [PubMed]

133. Senthilkumar, T.; Sangeetha, N.; Ashokkumar, N. Antihyperglycemic, antihyperlipidemic, and renoprotective effects of chlorella pyrenoidosa in diabetic rats exposed to cadmium. Toxicol. Mech. Methods 2012, 22, 617-624. [CrossRef]

134. Poontawee, W.; Natakankitkul, S.; Wongmekiat, O. Protective effect of Cleistocalyx nervosum var. Paniala fruit extract against oxidative renal damage caused by cadmium. Molecules 2016, 21, 133. [CrossRef]

135. Nishio, R.; Tamano, H.; Morioka, H.; Takeuchi, A.; Takeda, A. Intake of heated leaf extract of coriandrum sativum contributes to resistance to oxidative stress via decreases in heavy metal concentrations in the kidney. Plant. Foods Hum. Nutr 2019, 74, 204-209. [CrossRef]

136. Tubsakul, A.; Sangartit, W.; Pakdeechote, P.; Kukongviriyapan, V.; Apaijit, K.; Kukongviriyapan, U. Curcumin mitigates hypertension, endothelial dysfunction and oxidative stress in rats with chronic exposure to lead and cadmium. Tohoku J. Exp. Med. 2021, 253, 69-76. [CrossRef] 
137. Fan, S.R.; Ren, T.T.; Yun, M.Y.; Lan, R.; Qin, X.Y. Edaravone attenuates cadmium-induced toxicity by inhibiting oxidative stress and inflammation in icr mice. Neurotoxicology 2021, 86, 1-9. [CrossRef]

138. Kopec, A.; Sikora, E.; Piatkowska, E.; Borczak, B.; Czech, T. Possible protective role of elderberry fruit lyophilizate against selected effects of cadmium and lead intoxication in wistar rats. Environ. Sci. Pollut Res. Int. 2016, 23, 8837-8848. [CrossRef] [PubMed]

139. Chen, J.; Du, L.; Li, J.; Song, H. Epigallocatechin-3-gallate attenuates cadmium-induced chronic renal injury and fibrosis. Food Chem. Toxicol. 2016, 96, 70-78. [CrossRef] [PubMed]

140. Liu, E.; Han, L.; Wang, J.; He, W.; Shang, H.; Gao, X.; Wang, T. Eucommia ulmoides bark protects against renal injury in cadmium-challenged rats. J. Med. Food 2012, 15, 307-314. [CrossRef] [PubMed]

141. Elkhadragy, M.F.; Al-Olayan, E.M.; Al-Amiery, A.A.; Abdel Moneim, A.E. Protective effects of fragaria ananassa extract against cadmium chloride-induced acute renal toxicity in rats. Biol. Trace Elem. Res. 2018, 181, 378-387. [CrossRef]

142. Onwuka, F.C.; Erhabor, O.; Eteng, M.U.; Umoh, I.B. Protective effects of ginger toward cadmium-induced testes and kidney lipid peroxidation and hematological impairment in albino rats. J. Med. Food 2011, 14, 817-821. [CrossRef]

143. Veljkovic, A.R.; Nikolic, R.S.; Kocic, G.M.; Pavlovic, D.D.; Cvetkovic, T.P.; Sokolovic, D.T.; Jevtovic, T.M.; Basic, J.T.; Laketic, D.M.; Marinkovic, M.R.; et al. Protective effects of glutathione and lipoic acid against cadmium-induced oxidative stress in rat's kidney. Ren Fail. 2012, 34, 1281-1287. [CrossRef]

144. Mohamed, N.E. Effect of aqueous extract of glycyrrhiza glabra on the biochemical changes induced by cadmium chloride in rats. Biol. Trace Elem. Res. 2019, 190, 87-94. [CrossRef]

145. Chen, Q.; Zhang, R.; Li, W.M.; Niu, Y.J.; Guo, H.C.; Liu, X.H.; Hou, Y.C.; Zhao, L.J. The protective effect of grape seed procyanidin extract against cadmium-induced renal oxidative damage in mice. Environ. Toxicol. Pharmacol. 2013, 36, 759-768. [CrossRef]

146. Claudio, S.R.; Pidone Ribeiro, F.A.; De Lima, E.C.; Santamarina, A.B.; Pisani, L.P.; Pereira, C.S.D.; Fujiyama Oshima, C.T.; Ribeiro, D.A. The protective effect of grape skin or purple carrot extracts against cadmium intoxication in kidney of rats. Pathophysiology 2019, 26, 263-269. [CrossRef] [PubMed]

147. Winiarska-Mieczan, A. The potential protective effect of green, black, red and white tea infusions against adverse effect of cadmium and lead during chronic exposure-A rat model study. Regul. Toxicol. Pharmacol. 2015, 73, 521-529. [CrossRef]

148. Ranieri, M.; Di Mise, A.; Difonzo, G.; Centrone, M.; Venneri, M.; Pellegrino, T.; Russo, A.; Mastrodonato, M.; Caponio, F.; Valenti, G.; et al. Green olive leaf extract (ole) provides cytoprotection in renal cells exposed to low doses of cadmium. PLoS ONE 2019, 14, e0214159. [CrossRef] [PubMed]

149. Dua, T.K.; Dewanjee, S.; Khanra, R.; Bhattacharya, N.; Bhaskar, B.; Zia-Ul-Haq, M.; De Feo, V. The effects of two common edible herbs, ipomoea aquatica and enhydra fluctuans, on cadmium-induced pathophysiology: A focus on oxidative defence and anti-apoptotic mechanism. J. Transl. Med. 2015, 13, 245. [CrossRef] [PubMed]

150. Ojo, O.A.; Ajiboye, B.O.; Oyinloye, B.E.; Ojo, A.B.; Olarewaju, O.I. Protective effect of irvingia gabonensis stem bark extract on cadmium-induced nephrotoxicity in rats. Interdiscip. Toxicol. 2014, 7, 208-214. [CrossRef]

151. Aksoy, N.; Dogan, Y.; Iriadam, M.; Bitiren, M.; Uzer, E.; Ozgonul, A.; Aksoy, S. Protective and therapeutic effects of licorice in rats with acute tubular necrosis. J. Ren. Nutr. 2012, 22, 336-343. [CrossRef]

152. Lan, Z.; Bi, K.S.; Chen, X.H. Ligustrazine attenuates elevated levels of indoxyl sulfate, kidney injury molecule- 1 and clusterin in rats exposed to cadmium. Food Chem Toxicol. 2014, 63, 62-68. [CrossRef]

153. Luo, T.; Liu, G.; Long, M.; Yang, J.; Song, R.; Wang, Y.; Yuan, Y.; Bian, J.; Liu, X.; Gu, J.; et al. Treatment of cadmium-induced renal oxidative damage in rats by administration of alpha-lipoic acid. Environ. Sci. Pollut. Res. Int. 2017, 24, 1832-1844. [CrossRef]

154. Suru, S.M. Onion and garlic extracts lessen cadmium-induced nephrotoxicity in rats. Biometals 2008, 21, 623-633. [CrossRef]

155. Shati, A.A. Effects of origanum majorana 1. On cadmium induced hepatotoxicity and nephrotoxicity in albino rats. Saudi Med. J. 2011, 32, 797-805.

156. Osukoya, O.A.; Oyinloye, B.E.; Ajiboye, B.O.; Olokode, K.A.; Adeola, H.A. Nephroprotective and anti-inflammatory potential of aqueous extract from persea americana seeds against cadmium-induced nephrotoxicity in wistar rats. Biometals 2021, 34, 1141-1153. [CrossRef]

157. Dkhil, M.A.; Al-Quraishy, S.; Diab, M.M.; Othman, M.S.; Aref, A.M.; Abdel Moneim, A.E. The potential protective role of physalis peruviana 1. Fruit in cadmium-induced hepatotoxicity and nephrotoxicity. Food Chem Toxicol. 2014, 74, 98-106. [CrossRef]

158. Yadav, N.; Khandelwal, S. Effect of picroliv on cadmium-induced hepatic and renal damage in the rat. Hum. Exp. Toxicol. 2006, 25, 581-591. [CrossRef]

159. Jung, H.Y.; Seo, D.W.; Hong, C.O.; Kim, J.Y.; Yang, S.Y.; Lee, K.W. Nephroprotection of plantamajoside in rats treated with cadmium. Environ. Toxicol. Pharmacol. 2015, 39, 125-136. [CrossRef]

160. Dkhil, M.A.; Diab, M.S.M.; Lokman, M.S.; El-Sayed, H.; Bauomy, A.A.; Al-Shaebi, E.M.; Al-Quraishy, S. Nephroprotective effect of pleurotus ostreatus extract against cadmium chloride toxicity in rats. An. Acad. Bras. Cienc. 2020, 92, e20191121. [CrossRef] [PubMed]

161. Shen, R.; Liu, D.; Hou, C.; Liu, D.; Zhao, L.; Cheng, J.; Wang, D.; Bai, D. Protective effect of potentilla anserina polysaccharide on cadmium-induced nephrotoxicity in vitro and in vivo. Food Funct. 2017, 8, 3636-3646. [CrossRef]

162. Song, X.B.; Liu, G.; Wang, Z.Y.; Wang, L. Puerarin protects against cadmium-induced proximal tubular cell apoptosis by restoring mitochondrial function. Chem. Biol. Interact. 2016, 260, 219-231. [CrossRef] [PubMed] 
163. Alshammari, G.M.; Al-Qahtani, W.H.; AlFaris, N.A.; Albekairi, N.A.; Alqahtani, S.; Eid, R.; Yagoub, A.E.A.; Al-Harbi, L.N.; Yahya, M.A. Quercetin alleviates cadmium chloride-induced renal damage in rats by suppressing endoplasmic reticulum stress through sirt1-dependent deacetylation of xbp-1s and eif2alpha. Biomed. Pharmacother 2021, 141, 111862. [CrossRef]

164. Zhang, Q.; Zhang, C.; Ge, J.; Lv, M.W.; Talukder, M.; Guo, K.; Li, Y.H.; Li, J.L. Ameliorative effects of resveratrol against cadmium-induced nephrotoxicity via modulating nuclear xenobiotic receptor response and pink1/parkin-mediated mitophagy. Food Funct. 2020, 11, 1856-1868. [CrossRef] [PubMed]

165. Ansari, M.N.; Aloliet, R.I.; Ganaie, M.A.; Khan, T.H.; Najeeb Ur, R.; Imam, F.; Hamad, A.M. Roflumilast, a phosphodiesterase 4 inhibitor, attenuates cadmium-induced renal toxicity via modulation of nf-kappab activation and induction of nqo1 in rats. Hum. Exp. Toxicol. 2019, 38, 588-597. [CrossRef]

166. Joardar, S.; Dewanjee, S.; Bhowmick, S.; Dua, T.K.; Das, S.; Saha, A.; De Feo, V. Rosmarinic acid attenuates cadmium-induced nephrotoxicity via inhibition of oxidative stress, apoptosis, inflammation and fibrosis. Int. J. Mol. Sci. 2019, 20, 2027. [CrossRef]

167. Abarikwu, S.O.; Njoku, R.C.; Lawrence, C.J.; Charles, I.A.; Ikewuchi, J.C. Rutin ameliorates oxidative stress and preserves hepatic and renal functions following exposure to cadmium and ethanol. Pharm. Biol. 2017, 55, 2161-2169. [CrossRef] [PubMed]

168. Rashwan, H.M.; Mohammed, H.E.; El-Nekeety, A.A.; Hamza, Z.K.; Abdel-Aziem, S.H.; Hassan, N.S.; Abdel-Wahhab, M.A. Bioactive phytochemicals from salvia officinalis attenuate cadmium-induced oxidative damage and genotoxicity in rats. Environ. Sci. Pollut Res. Int. 2021. [CrossRef]

169. He, L.; Zhang, Q.Q.; Lu, X.Y.; Li, X.X. [effects of water extract of salvia miltiorrhiza aganst renal injury on rats exposed to cadmium]. Zhonghua Yi Xue Za Zhi 2017, 97, 57-61. [PubMed]

170. Albasher, G.; Albrahim, T.; Aljarba, N.; Alharbi, R.I.; Alsultan, N.; Alsaiari, J.; Rizwana, H. Involvement of redox status and the nuclear-related factor 2 in protecting against cadmium-induced renal injury with sana makki (cassia senna 1.) pre-treatment in male rats. An. Acad. Bras. Cienc. 2020, 92, e20191237. [CrossRef] [PubMed]

171. Chen, H.; Li, P.; Shen, Z.; Wang, J.; Diao, L. Protective effects of selenium yeast against cadmium-induced necroptosis through mir-26a-5p/pten/pi3k/akt signaling pathway in chicken kidney. Ecotoxicol. Environ. Saf. 2021, 220, 112387. [CrossRef]

172. Bas, H.; Apaydin, F.G.; Kalender, S.; Kalender, Y. Lead nitrate and cadmium chloride induced hepatotoxicity and nephrotoxicity: Protective effects of sesamol on biochemical indices and pathological changes. J. Food Biochem. 2021, 45, e13769. [CrossRef]

173. Ansari, M.A.; Raish, M.; Ahmad, A.; Alkharfy, K.M.; Ahmad, S.F.; Attia, S.M.; Alsaad, A.M.S.; Bakheet, S.A. Sinapic acid ameliorate cadmium-induced nephrotoxicity: In vivo possible involvement of oxidative stress, apoptosis, and inflammation via nf-kappab downregulation. Environ. Toxicol. Pharmacol. 2017, 51, 100-107. [CrossRef]

174. Ramamurthy, C.H.; Subastri, A.; Suyavaran, A.; Subbaiah, K.C.; Valluru, L.; Thirunavukkarasu, C. Solanum torvum swartz. Fruit attenuates cadmium-induced liver and kidney damage through modulation of oxidative stress and glycosylation. Environ. Sci. Pollut. Res. Int. 2016, 23, 7919-7929. [CrossRef]

175. Mzoughi, Z.; Souid, G.; Timoumi, R.; Le Cerf, D.; Majdoub, H. Partial characterization of the edible spinacia oleracea polysaccharides: Cytoprotective and antioxidant potentials against cd induced toxicity in hct116 and hek293 cells. Int. J. Biol. Macromol. 2019, 136, 332-340. [CrossRef]

176. Fouad, A.A.; Jresat, I. Protective effect of telmisartan against cadmium-induced nephrotoxicity in mice. Life Sci. 2011, 89, 29-35. [CrossRef]

177. Mostafa, D.G.; Ahmed, S.F.; Hussein, O.A. Protective effect of tetrahydrobiopterin on hepatic and renal damage after acute cadmium exposure in male rats. Ultrastruct. Pathol. 2018, 42, 516-531. [CrossRef] [PubMed]

178. Junsi, M.; Takahashi Yupanqui, C.; Usawakesmanee, W.; Slusarenko, A.; Siripongvutikorn, S. Thunbergia laurifolia leaf extract increased levels of antioxidant enzymes and protected human cell-lines in vitro against cadmium. Antioxidants $2020,9,47$. [CrossRef] [PubMed]

179. Ansari, M.N.; Rehman, N.U.; Karim, A.; Imam, F.; Hamad, A.M. Protective effect of thymus serrulatus essential oil on cadmiuminduced nephrotoxicity in rats, through suppression of oxidative stress and downregulation of nf-kappab, inos, and smad2 mrna expression. Molecules 2021, 26, 1252. [CrossRef] [PubMed]

180. Fouad, A.A.; Alwadaani, H.A.; Jresat, I. Protective effect of thymoquinone against nephrotoxicity induced by cadmium in rats. Intenrational Sch. Sci. Res. Innov. 2016, 10, 73-76.

181. Padma, V.V.; Baskaran, R.; Divya, S.; Priya, L.B.; Saranya, S. Modulatory effect of tinospora cordifolia extract on cd-induced oxidative stress in wistar rats. Integr. Med. Res. 2016, 5, 48-55. [CrossRef]

182. Fan, R.F.; Li, Z.F.; Zhang, D.; Wang, Z.Y. Involvement of nrf2 and mitochondrial apoptotic signaling in trehalose protection against cadmium-induced kidney injury. Metallomics 2020, 12, 2098-2107. [CrossRef] [PubMed]

183. Lakshmi, G.D.; Kumar, P.R.; Bharavi, K.; Annapurna, P.; Rajendar, B.; Patel, P.T.; Kumar, C.S.; Rao, G.S. Protective effect of tribulus terrestris linn on liver and kidney in cadmium intoxicated rats. Indian J. Exp. Biol 2012, 50, 141-146.

184. Ali, S.; Hussain, S.; Khan, R.; Mumtaz, S.; Ashraf, N.; Andleeb, S.; Shakir, H.A.; Tahir, H.M.; Khan, M.K.A.; Ulhaq, M. Renal toxicity of heavy metals (cadmium and mercury) and their amelioration with ascorbic acid in rabbits. Environ. Sci. Pollut. Res. Int. 2019, 26, 3909-3920. [CrossRef]

185. Fang, J.; Xie, S.; Chen, Z.; Wang, F.; Chen, K.; Zuo, Z.; Cui, H.; Guo, H.; Ouyang, P.; Chen, Z.; et al. Protective effect of vitamin e on cadmium-induced renal oxidative damage and apoptosis in rats. Biol. Trace Elem. Res. 2021, 199, 4675-4687. [CrossRef]

186. Yu, J.; Liu, Y.; Guo, J.; Tao, W.; Chen, Y.; Fan, X.; Shen, J.; Duan, J.A. Health risk of licorice-yuanhua combination through induction of colonic h2s metabolism. J. Ethnopharmacol. 2019, 236, 136-146. [CrossRef] [PubMed] 
187. Van Cauwenberghe, C.; Vandendriessche, C.; Libert, C.; Vandenbroucke, R.E. Caloric restriction: Beneficial effects on brain aging and alzheimer's disease. Mamm. Genome 2016, 27, 300-319. [CrossRef]

188. Estrela, G.R.; Wasinski, F.; Batista, R.O.; Hiyane, M.I.; Felizardo, R.J.; Cunha, F.; de Almeida, D.C.; Malheiros, D.M.; Camara, N.O.; Barros, C.C.; et al. Caloric restriction is more efficient than physical exercise to protect from cisplatin nephrotoxicity via ppar-alpha activation. Front. Physiol. 2017, 8, 116. [CrossRef] [PubMed]

189. Sohal, R.S.; Forster, M.J. Caloric restriction and the aging process: A critique. Free Radic. Biol. Med. 2014, 73, 366-382. [CrossRef]

190. Sohal, R.S.; Weindruch, R. Oxidative stress, caloric restriction, and aging. Science 1996, 273, 59-63. [CrossRef]

191. Shaikh, Z.A.; Jordan, S.A.; Tang, W. Protection against chronic cadmium toxicity by caloric restriction. Toxicology 1999, 133, 93-103. [CrossRef]

192. Felley-Bosco, E.; Diezi, J. Dietary calcium restriction enhances cadmium-induced metallothionein synthesis in rats. Toxicol. Lett. 1992, 60, 139-144. [CrossRef]

193. Jin, Z.; Wu, J.; Yan, L.J. Chemical conditioning as an approach to ischemic stroke tolerance: Mitochondria as the target. Int. J. Mol. Sci. 2016, 17, 351. [CrossRef] [PubMed]

194. Wu, J.; Li, R.; Li, W.; Ren, M.; Thangthaeng, N.; Sumien, N.; Liu, R.; Yang, S.; Simpkins, J.W.; Forster, M.J.; et al. Administration of 5-methoxyindole-2-carboxylic acid that potentially targets mitochondrial dihydrolipoamide dehydrogenase confers cerebral preconditioning against ischemic stroke injury. Free Radic. Biol. Med. 2017, 113, 244-254. [CrossRef]

195. Wu, J.; Jin, Z.; Yang, X.; Yan, L.J. Post-ischemic administration of 5-methoxyindole-2-carboxylic acid at the onset of reperfusion affords neuroprotection against stroke injury by preserving mitochondrial function and attenuating oxidative stress. Biochem. Biophys. Res. Commun. 2018, 497, 444-450. [CrossRef]

196. Kim, J.J.; Kim, Y.S.; Kumar, V. Heavy metal toxicity: An update of chelating therapeutic strategies. J. Trace Elem. Med. Biol. 2019, 54, 226-231. [PubMed]

197. Akiyama, M.; Unoki, T.; Shinkai, Y.; Ishii, I.; Ida, T.; Akaike, T.; Yamamoto, M.; Kumagai, Y. Environmental electrophile-mediated toxicity in mice lacking nrf2, cse, or both. Environ. Health Perspect. 2019, 127, 67002. [CrossRef] [PubMed]

198. Shinkai, Y.; Masuda, A.; Akiyama, M.; Xian, M.; Kumagai, Y. Cadmium-mediated activation of the hsp90/hsf1 pathway regulated by reactive persulfides/polysulfides. Toxicol. Sci. 2017, 156, 412-421. [PubMed]

199. Akiyama, M.; Shinkai, Y.; Unoki, T.; Shim, I.; Ishii, I.; Kumagai, Y. The capture of cadmium by reactive polysulfides attenuates cadmium-induced adaptive responses and hepatotoxicity. Chem. Res. Toxicol. 2017, 30, 2209-2217. [CrossRef]

200. Bonventre, J.V. Dedifferentiation and proliferation of surviving epithelial cells in acute renal failure. J. Am. Soc. Nephrol. 2003, 14, S55-S61. [CrossRef]

201. Padanilam, B.J. Cell death induced by acute renal injury: A perspective on the contributions of apoptosis and necrosis. Am. J. Physiol. Renal Physiol. 2003, 284, F608-F627. [CrossRef]

202. Chang-Panesso, M.; Humphreys, B.D. Cellular plasticity in kidney injury and repair. Nat. Rev. Nephrol. 2017, 13, 39-46. [CrossRef]

203. Chang-Panesso, M.; Kadyrov, F.F.; Lalli, M.; Wu, H.; Ikeda, S.; Kefaloyianni, E.; Abdelmageed, M.M.; Herrlich, A.; Kobayashi, A.; Humphreys, B.D. Foxm1 drives proximal tubule proliferation during repair from acute ischemic kidney injury. J. Clin. Investig. 2019, 129, 5501-5517. [CrossRef]

204. Moulis, J.M. Cellular mechanisms of cadmium toxicity related to the homeostasis of essential metals. Biometals 2010, 23, 877-896. [CrossRef] [PubMed]

205. Fujiwara, Y.; Lee, J.Y.; Tokumoto, M.; Satoh, M. Cadmium renal toxicity via apoptotic pathways. Biol. Pharm. Bull. 2012, 35, 1892-1897. [CrossRef] [PubMed] 